Jukka Mähönen*

\title{
Integrated Reporting and Sustainable Corporate Governance from European Perspective
}

https://doi.org/10.1515/ael-2018-0048

Abstract: According to the Cadbury Committee (1992) classical definition, corporate governance is 'the system by which companies are directed and controlled.' In the Cadbury Report and in other mainstream corporate governance codes, 'system' refers only to the 'financial aspects of corporate governance', that is, shareholder value and emphasis on the board's and the management's accountability to providers of financial capital only. During the last few years however, sustainability has been included through 'integrated reporting' in corporate governance codes especially in Africa (South Africa) and Asia (Malaysia, Philippines). For example, the South African King reports on corporate governance connect the use of integrated reporting to report on an organisation's corporate governance practices and economic-social-environmental triple-bottom-line performance.

The leading normative framework for integrated reporting, the International Integrated Reporting Council's International <IR $>$ Framework, is based on an idea of 'shared value creation' by providers of the 'six capitals' (financial, manufactured, intellectual, human, societal and environmental capitals). As such integrated reporting represents a stakeholder management model already integrated - at least on the text level - in many corporate governance codes, just enlarging the concept of capital providers from shareholders only to other internal stakeholders, and the goal of capital efficiency and profit maximisation from financial capital only to other five forms of internal capital provisions. It is also a new step in the development of social and environmental accounting and reporting, rooting from the 1970s and sustainability reporting from the 1990s.

The concept of a 'business model' represents the way how an organisation creates value, comprising all its activities, its relationships with stakeholders and its tangible and intangible assets and liabilities, and finally the boards responsibilities, as for the board, 'corporate governance' and sustaining and developing the company's business model are essentially the same thing. In the end of the day, it is a question what kind of 'business model' integrated

*Corresponding author: Jukka Mähönen, Faculty of Law, University of Oslo, Postboks 6706, St. Olavs plass, Oslo 0130, Norway, E-mail: jukka.mahonen@jus.uio.no 
reporting based corporate governance really reflects, and how it possible varies from shareholder-centred business model.

The purpose of this paper is to test (1) what kind of stakeholder model, if any, integrated reporting and especially International <IR $>$ Framework represents, (2) what is the impact, if any, of integrated reporting to material corporate governance in the codes it is included in, and (3) if yes, does an integrated view and especially the 'integrated thinking' behind International <IR $>$ Framework represent a genuine sustainable value creation driven business model based on the boundaries of the planet and social foundation for the humanity, or is it only a view to encourage organisations to take care of the profits of the specific capital providers.

Keywords: integrated reporting, integrated thinking, corporate governance

Jel Codes: G3, M41, M42

\section{Table of Contents}

1. Introduction

2. The International $\langle\mid R\rangle$ Framework, integrated thinking and business model

3. Business model in integrated thinking and integrated reporting

4. Integrated thinking in corporate governance

5. Use of integrated reporting in corporate governance

6. Why integrated reporting is failing?

7. Conclusion

Reference

\section{Rethinking Non-Financial Reporting: A Blueprint for Structural Regulatory Changes}

1. Beyond Non-Financial Reporting: A Blueprint for Deep Structural Regulatory Changes, by David Monciardini, https://doi.org/10.1515/ael-2020-0092.

2. Non-Financial Reporting \& Corporate Governance: Explaining American Divergence \& Its Implications of Disclosure Reform, by Virginia Harper Ho, https://doi.org/10.1515/ael2018-0043.

3. The impact of climate change in the valuation of production assets via the IFRS framework An exploratory qualitative comparative case study approach, by Rebecca Scholten, https:// doi.org/10.1515/ael-2018-0032.

4. A country-comparative analysis of the transposition of the EU Non-Financial Directive an institutional approach by Selena Aureli, https://doi.org/10.1515/ael-2018-0047.

5. The Challenges of Assurance on Non-financial Reporting, by Amanda Ling Li Sonnerfeldt, https://doi.org/10.1515/ael-2018-0050.

6. Integrated reporting and sustainable corporate governance from European perspective, by Jukka Tapio Mähönen, https://doi.org/10.1515/ael-2018-0048.

7. Why 'less is more' in non-financial reporting initiatives: concreate steps towards supporting sustainability, by Georgina Tsagas, https://doi.org/10.1515/ael-2018-0045.

8. Planetary boundaries and corporate reporting the role of the conceptual basis of the corporation, by Andreas Jansson, https://doi.org/10.1515/ael-2018-0037. 
9. The financialization of civil society activism: sustainable finance and the shrinking of bottom-up engagement, by Davide Cerrato, https://doi.org/10.1515/ael-2019-0006.

10. Paradise Lost Accounting Narratives Without Numbers, by Mario-Abela, https://doi.org/ 10.1515/ael-2019-0035.

\section{Introduction}

Integrated reporting is like God: no one has met Him, but everybody talks about Him ${ }^{1}$

According to the Cadbury Committee (1992) classical definition, corporate governance is 'the system by which companies are directed and controlled.' In the Cadbury Report and in other mainstream corporate governance codes, a 'system' refers however only to the 'financial aspects of corporate governance', ${ }^{3}$ that is, shareholder value and emphasis on the board's and the management's accountability to providers of financial capital, ${ }^{4}$ or as put in the Report itself, effective accountability 'is the essence of any system of good corporate governance ${ }^{5}$ and 'issue for corporate governance is how to strengthen the accountability of boards of directors to shareholders. ${ }^{6}$

During the last few decades however, demands to integrate both stakeholder and material environmental, social and governance (ESG) considerations into investment and value creation decision-making processes have increased among investors. ${ }^{7}$ The mostly United Kingdom (UK) based social and environmental

1 Delphine Gibassier, Michelle Rodrigue and Diane-Laure Arjeliès, “"Integrated reporting is like God: no one has met Him, but everybody talks about Him": The power of myths in the adoption of management innovations', Accounting, Auditing \& Accountability Journal, 31(5) (2018), 1349 - 1380. 2 Report of the Committee on The Financial Aspects of Corporate Governance (Cadbury Report), December 1, 1992, II 2.5; see Jean J. Du Plessis and Chee Keong Low, 'Corporate Governance Codes Under the Spotlight' in Jean Jacques Du Plessis and Chee Keong Low (eds), Corporate Governance Codes for the twenty-first Century: International Perspectives and Critical Analyses (Cham: Springer, 2017), pp. 3-20, p. 3.

3 Cadbury Report 甲ा 2.6.

4 Cadbury Report 9 1 3.4.

5 Cadbury Report II 1.1, see Andrew Keay, 'An Analytical Study of Board Accountability in Transnational Codes of Corporate Governance' in Jean Jacques Du Plessis and Chee Keong Low (eds), Corporate Governance Codes for the twenty-first Century: International Perspectives and Critical Analyses (Cham: Springer, 2017), pp. 117-143, p. 122.

6 Cadbury Report 9ा 6.1, see Keay, 'An Analytical Study’, p. 118.

7 See, for instance, EU High-Level Expert Group on Sustainable Finance, Financing a Sustainable European Economy: Interim Report (July 2017) p. 24, https://ec.europa.eu/info/ publications/170713-sustainable-finance-report_en. 
accounting (SEA) and reporting (SER) movements, beginning as social accounting in the 1970s, sometimes called as 'corporate social responsibility' (CSR) reporting and enlargement to environmental accounting in the $1990 \mathrm{~s}^{8}$ reporting of social, environmental and financial considerations coined as 'triple bottom line' by John Elkington in 1997,' and finally 'sustainability reporting', finally captured by the United States (US) based Global Reporting Initiative ${ }^{10}$ (GRI) founded in 1997, have been phases in this saga. ${ }^{11}$ In practice it was of the CSR movement focussing corporate attention not only shareholders but also corporate activities' environmental, social and ethical contexts, ${ }^{12}$ emphasising the ' $\mathrm{S}$ ' in the ESG, through the requirement to take into consideration the interests of the firm's 'stakeholders', those heterogenous groups or individuals with their private interests who can affect or is affected by the achievement of the firm's objectives. ${ }^{13}$ The CSR approach has affected not only corporate governance models but corporate governance codes themselves. ${ }^{14}$ The normative struggle between shareholder view and stakeholder view can be seen even in the UK

8 Rob Gray, 'Social and Environmental Accounting and Reporting: From Ridicule to Revolution? From Hope to Hubris? - A Personal Review of the Field', Issues in Social and Environmental Accounting 2(1) (2008), pp. 3-18 and the extensive literature referred to in it.

9 John Elkington, Cannibals with forks: The triple bottom line of Twenty-first century business (Oxford: Capstone, 1997).

10 www.globalreporting.org.

11 José M. Moneva, Pablo Archel and Carmen Correa, 'GRI and the camouflaging of corporate unsustainability', Accounting Forum 30 (2006), pp. 121-137.

12 Chris Marsden, 'Economics, the Financial Crisis and Corporate Responsibility', Corporate Governance: The International Journal of Business in Society, 10(4) (2010), pp. 360 - 364, p. 362; Irene-Marie Esser, 'Corporate Social Responsibility: A Company Law Perspective, South African Mercantile Law Journal 23 (2011), pp. 317 - 335, p. 319; Daniél Gergely Szabó and Karsten Engsig Sørensen, 'Integrating Corporate Social Responsibility in Corporate Governance Codes in the EU' (2013) 24(6) European Business Law Review 24(6) (2013), pp. 781 - 828, p. 783 - 784.

13 This standard definition of a 'stakeholder' comes from R. Edward Freeman, Strategic Management: A Stakeholder Approach (Boston: Pitman, 1984) p. 46. However, the 'stakeholder' concept is older in Scandinavia, deriving from Eric Rhenman, Företagsdemokrati och företagsorganisation [Industrial democracy and industrial management] (Stockholm: Thule, 1964) ('intressent'); see Juha Näsi, 'A Scandinavian approach to stakeholder thinking: An analysis of its theoretical and practical uses, 1964-1980' in Juha Näsi (ed.), Understanding Stakeholder Thinking (Helsinki: LSR-Julkaisut Oy, 1995), pp. 97-115, p. 98; see Robert Strand and R. Edward Freeman, 'Scandinavian Cooperative Advantage: The Theory and Practice of Stakeholder Engagement in Scandinavia', Journal of Business Ethics 27 (2015), pp. 65 - 85, p. 68. The concept is highly used in corporate discussion, but at the same time highly problematic for instance in corporate law context, as it is not based on law.

14 Szabó and Sørensen, 'Integrating'. 
legal discussion on the enlightened shareholder value (ESV), based on the UK Companies Act 2006 section 172. ${ }^{15}$

The discussion on ESV shows however clearly the problem of stakeholder approach, stakeholders having only instrumental value to the shareholders, instead of having a value of their own, ${ }^{16}$ shown also by the 'CSR industry': consultants, NGOs, professional bodies, governmental bodies, and public relations experts trying to sell in their part the idea of a socially responsible behaviour as a tool enhancing shareholder value. ${ }^{17}$ The CSR discussion shows also its nature as a business case, making sustainability to serve shareholder value maximization, as shareholder-centrist approach to stakeholders helps the firms' management avoid a conflict of objectives arising from the consideration of the firms' heterogeneous target groups by concentrating on the interest of the firms' 'owners' and how the organization generate value to them. ${ }^{18}$

At the same time however, due to the inescapable externalities caused by business organizations, they have come under pressure to adapt their business practices to consider the increasing public awareness of ESG issues. In the minimum, organizations are required be transparent on their ESG performance. ${ }^{19}$

15 See, eg, Virginia Harper Ho, “'Enlightened Shareholder Value”: Corporate Governance beyond the Shareholder-Stakeholder Divide' (2010) 36(1) Journal of Corporation Law 36(1) (2010), pp. 59 - 112; Andrew Keay, 'Moving towards Stakeholderism? Constituency Statutes, Enlightened Shareholder Value, and More: Much Ado about Little?' (2011) 22(1) European Business Law Review 22(1) (2011), pp. 1 - 49; Andrew Keay, The Enlightened Shareholder Value Principle and Corporate Governance (Abingdon: Routledge 2013); Sulette Lombard and Tronel Joubert, 'The Legislative Response to the Shareholders V Stakeholders Debate: A Comparative Overview', Journal of Corporate Law Studies, 14:1 (2014), pp. 211 - 240; Georgina Tsagas, 'Section 172 of the Companies Act 2006: Desperate Times Call for Soft Law Measures' in Nina Boeger and Charlotte Villiers (eds) Shaping the Corporate Landscape: Towards Corporate Reform and Enterprise Diversity (Oxford and Portland, Oregon: Hart Publishing, 2018) pp. 131 - 150.

16 Andrew Keay, The Corporate Objective (Oxford: Edward Elgar, 2011), pp. 116-117; Carol A. Adams and Glen Whelan, 'Conceptualising future change in corporate sustainability reporting', Accounting, Auditing \& Accountability Journal, 22:1 (2009), pp. 118 - 143, p. 134; Lombard and Joubert, 'The Legislative Response', p. 219.

17 Adams and Whelan, 'Conceptualising future change', p. 134.

18 Patrick Velte and Martin Stawinoga, 'Integrated reporting: The current state of empirical research, limitations and future research implications', Journal of Management Control, 28:3 (2017), 275-320, p. 276. In limited liability enterprises as companies and cooperatives the shareholders and members do not own the corporate assets as the entity itself owns its own assets, the shareholders and members having decision-making rights and economic rights in the entity.

19 Patrick Velte and Martin Stawinoga, 'Integrated reporting: The current state of empirical research, limitations and future research implications', Journal of Management Control, 28:3 (2017), 275-320, p. 276. 
A partial answer to these demands have been different kinds of 'triple bottom line' (TBL), 'corporate social responsibility' and 'sustainability' ${ }^{20}$ reports and their standardizations, as Global Reporting Initiative (GRI) and International Organization of Standardization (ISO) standard 26,000, referred also in the European Union's directive 2014/95/EU as 'non-financial reporting'21. However, the main problem is that - due to lack of true sustainability basis in them sustainability in these reports has remained biased. The meanings of sustainability, corporate social responsibility and related terms are ambiguous and companies are often uncertain how to define and implement sustainability. ${ }^{22}$ For instance the GRI has been seen from its beginning flawed towards social equity and human rights, ${ }^{23}$ and as such representing the weak form of sustainability. ${ }^{24}$ The GRI framework provides standardisation by requiring participants to report on economic indicators, environmental compliance, labour practices, human rights, society and product responsibility, but within these categories and subcategories, the framework allows each company the flexibility to report on issues of most salience for the company and its perceived stakeholders. ${ }^{25}$ At its best a traditional sustainability report is more 'a means towards more sustainable societies', rather than as about improving reporting quality to support sustainable financial investment and business model decisions that is supposed to be the ultimate purpose of

20 The exact meaning of 'sustainability' is ambiguous. This 'constructive ambiguity' of sustainability makes the concept flexible, as it can be translated in a range of actions adapted to the needs and possibilities of a diverse set of stakeholders. However, although constructive ambiguity is useful for gaining broad support, it entails the risk that the concept becomes meaningless. If sustainability is to move beyond the gap between rhetoric and action, it should become a decision-guiding strategy, defined as a way forward to a desired future. John Robinson, 'Squaring the circle? Some thoughts on the idea of sustainable development', Ecological Economics, 48 (2004), 369-384, p. 374; Jean Huge', Tom Waas, Farid DahdouhGuebas, Nico Koedam and Thomas Block, 'A discourse-analytical perspective on sustainability assessment: interpreting sustainable development in practice', Sustainability Science, 8:2(2013), 187-198; Marlies Hueskes, Koen Verhoest and Thomas Block, 'Governing public-private partnerships for sustainability: An analysis of procurement and governance practices of PPP infrastructure projects', International Journal of Project Management, 35 (2017), 1184-1195, p. 1186.

21 Directive 2014/95/EU of the European Parliament and of the Council of October 22, 2014 amending Directive 2013/34/EU as regards disclosure of non-financial and diversity information by certain large undertakings and groups, OJ L 330, 15.11.2014, p. 1-9.

22 Nancy E. Landrum and Brian Ohsowski, 'Identifying Worldviews on Corporate Sustainability: A Content Analysis of Corporate Sustainability Reports', Business Strategy and the Environment 27 (2018), pp. 128-151, p. 130.

23 Moneva, Archer and Correa, 'GRI and the camouflaging', p. 122.

24 Moneva, Archer and Correa, 'GRI and the camouflaging', p. 130.

25 Landrum and Ohsowski, ‘Identifying Worldviews on Corporate Sustainability’, p. 130. 
the 'sustainability' reports of business firms. ${ }^{26}$ In its worst it communicates weak sustainability the business case only, entrenched in the technocentric worldview of humans' exploitation and control over nature, with little mention to science and planetary boundaries. ${ }^{27}$

The consequence from this, an ambiguity and an emptiness of 'sustainability' concepts in reporting can be seen during the last decades in the discussion on the difference between weak and strong sustainability. ${ }^{28}$ Weak sustainability builds on a 'business as usual', on a strong belief in technological and innovative solutions for environmental problems and the shortage of raw materials, as technological progress is assumed to continually generate technical solutions to the environmental problems caused by the increased production of goods and services (techno-optimism). ${ }^{29}$ It relies mostly on reporting and transparency, which comprise key planks of modern risk management and investor governance. ${ }^{30}$ In weak sustainability, reduction of natural assets from geology, soil, air, water and all living things ('natural capital' or 'ecosystem services') can be compensated increase in manufactured capital, or other sources of capital as human capital or social and relationship capital. ${ }^{31}$

26 Dale Tweedie and Nonna Martinov-Bennie, 'Entitlements and Time: Integrated Reporting's Double-edged Agenda', Social and Environmental Accountability Journal, 35(1) (2015), 49 - 61, 49. 27 Landrum and Ohsowski, 'Identifying Worldviews on Corporate Sustainability', p. 138 - 139, 143. 28 Erik Neumayer, Weak Versus Strong Sustainability: Exploring the Limits of Two Opposing Paradigms (Cheltenham: Edward Elgar Publishing, 2003); Moneva, Archer and Correa, 'GRI and the camouflaging'; Nigel Roome, 'Looking Back, Thinking Forward: Distinguishing Between Weak and Strong Sustainability' in Pratima Bansal and Andrew J. Hoffman (eds), The Oxford Handbook of Business and the Natural Environment (November 2011) doi: 10.1093/ oxfordhb/9,780,199,584,451.003.0034; Erling Holden, Kristin Linnerud and David Banister, 'Sustainable development: Our Common Future revisited', Global Environmental Change 26 (2014), 130-139, 132.

29 Paul Ekins, Sandrine Simon, Lisa Deutsch, Carl Folke and Rudolf De Groot, 'A framework for the practical application of the concepts of critical natural capital and strong sustainability', Ecological Economics, 44 (2003), 165-185; Holden, Linnerud and Banister, 'Sustainable development', 132.

30 Roome, 'Looking back'.

31 Peter A. Victor, 'Indicators of sustainable development: some lessons from capital theory', Ecological Economics, 4(3) (1991), 191 - 213; Holden, Linnerud and Banister, 'Sustainable development', 132. On financial capital, manufacturing capital, human capital, social and relationship capital, intellectual capital and natural capital (the 'six capitals'), see Jane Gleeson-White, Six Capitals: The revolution capitalism has to have - or can accountants save the planet? (Sydney: Allen and Unwin, 2014). On natural capital see World Forum on Natural Capital, What is natural capital?, https://naturalcapitalforum.com/about/; Natural Capital Coalition, What is natural capital?, https://naturalcapitalcoalition.org/natural-capital-2/. 
In contrast, strong sustainability questions the existing dominant market structures and pleads for more radical transformations, as conventional economics does not adequately reflect the value of essential factors like clean air and water, species diversity, and social and generational equity. ${ }^{32}$ In strong sustainability offset between capitals is not acceptable as critical natural capital cannot be replaced by other forms of capital due to uncertainty about ecosystem functions, the irreversibility of some components of natural capital if damaged, and the aversion felt by many people about environmental degradation. ${ }^{33}$ In the last end, if planetary boundaries, the processes that regulate the stability and resilience of the Earth system, ${ }^{34}$ are breached, no forms of natural capital are substitutable. Rather than viewing the three 'pillars' of sustainability (social, ecological, economic) as three distinct but complementary dimensions of sustainable development, ${ }^{35}$ for instance from the reporting and disclosure points of view, the stronger model of sustainability presupposes that economic activities serve a socially just society and that both can exist only within the planetary boundaries, seeking to integrate enterprises into socio-ecological systems, so that the patterns of production and consumption to which the company contributes are within the boundaries. ${ }^{36}$

On the other hand, if commitments to sustainability are taken seriously and to be turned into action, measurement issues must first be tackled, for instance the mark-to-market accounting rules for assets held in long-term portfolios in financial accounting (as in the International Financial Reporting Standards, IFRS). ${ }^{37}$ For this reason, specific sustainability indicators are essential for setting targets, monitoring progress and determining relative performance. At the same time radical changes in the institutional and economic structure of the society must be critically assessed. ${ }^{38}$ In consequence, strong sustainability requires fundamental change in the mental frame of capitalism. ${ }^{39}$ In the context of financial markets, traditional methods for promoting more informed investments in financial markets are likely to be

32 Herman E. Daly and Joshua Farley, Ecological Economics: Principles and Applications, 2nd ed. (Washington, DC: Island Press, 2011).

33 Holden, Linnerud and Banister, 'Sustainable development', 132.

34 On planetary boundaries see Stockholm Resilience Centre, Planetary boundaries research, https://www.stockholmresilience.org/research/planetary-boundaries.html.

35 Erling Holden, Kristin Linnerud and David Banister, 'Sustainable development: Our Common Future revisited', Global Environmental Change 26 (2014), 130-139.

36 Roome, 'Looking back'.

37 See Financing a Sustainable European Economy, Final Report, p. 48.

38 Hueskes, Verhoest and Block, 'Governing public-private partnerships', p. 1186.

39 Roome, 'Looking back'. 
deficient in tackling the most pressing environmental concerns. When applied to financial markets, weak sustainability is bound with existing market structures emphasising agency relationships, their problematics, especially information asymmetries, and disclosure and transparency requirements as a solution for them.

As an example of weak sustainability can be seen the development of the GRI, the most widely used guidance for 'sustainability' reporting and considered to be the de-facto sustainability reporting standard, aiming to provide for sustainability reporting what financial reporting standards as the US generally accepted accounting principles (GAAP) or the IFRS provide for financial reporting, and to harmonize the confusing field of sustainability reporting standards and frameworks. ${ }^{40}$ However, it has at least partly betrayed its original promises. ${ }^{41}$ Originally the GRI engaged with a broad stakeholder base including large companies, the financial sector, the accounting profession, civil society, environmental and human rights non-governmental organizations, organized labour, and others, to strengthen civil-private regulation and collaborative governance in order to shift the balance of power in corporate governance toward civil society and make corporations accountable to all stakeholders, not only those in investment supply chains. ${ }^{42}$

Later however the GRI has been criticized that its institutional logic has over the years moved away from empowering civil society and other actors to be dominated by a 'corporate social performance' (CSP) logic. ${ }^{43}$ GRI has been criticized on 'its apparent reluctance' to provide a definition of sustainability, sustainable development or 'sustainability principles'. This has led to concerns that companies could '... sell their GRI compliant report as a sign of "sustainable behaviour"' based on an assumption that that any references to the economic, the social and the environmental and their integration is consistent with sustainability or sustainable development. ${ }^{44}$ The GRI has been seen to change its

40 David L. Levy, Halina Szejnwald Brown and Martin de Jong, 'The Contested Politics of Corporate Governance: The Case of the Global Reporting Initiative', Business \& Society, 49:1 (2010), 88 - 115, p. 99; Stubbs and Higgins, 'Stakeholders' Perspectives', p. 495.

41 Stubbs and Higgins, 'Stakeholders' Perspectives', p. 495.

42 Hess, 'The Future of Sustainability Reporting', p. 131; Stubbs and Higgins, 'Stakeholders' Perspectives', p. 504.

43 David L. Levy, Halina Szejnwald Brown and Martin de Jong, 'The Contested Politics of Corporate Governance: The Case of the Global Reporting Initiative', Business \& Society, 49:1 (2010), 88 - 115, p. 90; Stubbs and Higgins, 'Stakeholders' Perspectives', p. 505.

44 Markus J. Milne and. Rob Gray, 'W(h)ither Ecology? The Triple Bottom Line, the Global Reporting Initiative, and Corporate Sustainability Reporting', Journal of Business Ethics, 118 (2013), 12 - 29, p. 19. 
primary purpose from empowering communities, consumers, non-governmental organizations and social investors to hold corporations accountable to the corporations themselves, in order to increase the use of their reporting standards. ${ }^{45}$ The end result is that while the GRI has successfully become institutionalized, its instrumental value for private regulation is seen as modest, as it is adjusting to markets of weak sustainability without demands of substantial accountability. ${ }^{46}$

Even more, they are seen more symbolic, 'as a form of insurance against future negative events', focused almost exclusively on positive information. On the other hand the 'stakeholders' hardly care, as these symbolic actions as opposed to true commitments to transparency - work as 'the other actors in the sustainability reporting organizational field seem to reward disclosures of any quality. ${ }^{47}$ Supporting this acceptance of symbolic actions are those organizations in the so called 'corporate social responsibility' field that rank corporations on the quantity of their disclosures, the number of indicators reported against, and not on their actual performance. 'Thus, simply reporting on more indicators - regardless of whether those disclosures are selective and actually work towards creating a misleading impression of the company's efforts and performance - can allow a corporation to be seen by stakeholders as working towards sustainable development. ${ }^{, 48}$

So, it is not wonder that a more integrated view to the capitals and reporting has been looked for, a view than can be described as 'integrated thinking' of governance and, following from that, an 'integrated reporting, ${ }^{49}$. Sustainability has been

45 Hess, 'The Future of Sustainability Reporting', p. 132.

46 Stubbs and Higgins, 'Stakeholders' Perspectives', p. 495.

47 Hess, 'The Future of Sustainability Reporting', pp. 129 - 130.

48 Hess, 'The Future of Sustainability Reporting', p. 130.

49 See Mandy Cheng, Wendy Green, Pieter Conradie, Noriyuki Konishi and Andrea Romi, 'The international integrated reporting framework: key issues and future research opportunities', Journal of International Financial Management \& Accounting, 25:1 (2014), 90-119.; Charl de Villiers, Leonardo Rinaldi and Jeffrey Unerman, 'Integrated Reporting: Insights, gaps and an agenda for future research', Accounting, Auditing \& Accountability Journal, $27: 7$ (2014), 10421067; Robert C. Eccles, Michael P. Krzus and Sydney Ribot, The Integrated Reporting Movement: Meaning, Momentum, Motives, and Materiality (Hoboken: John Wiley \& Sons, 2015); Charlotte Villiers and Jukka Mähönen, 'Article 11: Integrated Reporting or Non-Financial Reporting?' in Beate Sjåfjell and Anja Wiesbrock (eds), The Greening of European Business under EU Law Taking Article 11 TFEU Seriously (Abingdon: Routledge) pp. 118-143; David Monciardini, John Dumay and Lucia Biondi, 'Integrated Reporting and EU Law: Competing, Converging or Complementary Regulatory Frameworks?' (June 6, 2017), University of Oslo Faculty of Law Research Paper, No. 2017-23, available at SSRN: https://ssrn.com/abstract=2981674; Adhariani, Desi and de Villiers, Charl. 'Integrated reporting: perspectives of corporate report 
included through integrated reporting also in the corporate governance codes, especially in Africa (South Africa) and Asia (Malaysia ${ }^{50}$ and Philippines ${ }^{51}$ ). For example, the South African 'King reports' on corporate governance connect the use of integrated reporting to report on an organisation's corporate governance practices and economic-social-environmental triple-bottom-line performance. ${ }^{52}$

However, these kinds of integrated reports remain still easily superfluous compared to the organizations' financial reports or even attempts for sustainability reports. As sustainability reports have their focus on risk management and protecting the company's reputation, they can only operate within a weak sustainability paradigm that doesn't 'push corporations to radically rethink their operations (and even existence) and move towards sustainability in any meaningful way, ${ }^{53}$ These concerns are consistent with the view that 'corporate social responsibility' in general has been taken over by corporations as a managerial tool to manage risks and further marketing goals, as opposed to expectations of incorporating sustainable development into company values and operations. ${ }^{54}$ Secondly, discussion of 'sustainability' in accounting and reporting is not usually sustainability at all due to the negligence of social aspects emphasised in social and environmental accounting and reporting. What is often presented concerns environmental aspects of sustainability. In sustainability reporting as the GRI the absence of systematic consideration of social aspects of sustainability and sustainable development is evident. ${ }^{55}$ The basis of modern sustainability thinking, planetary boundaries model and the heuristic idea of social foundation

preparers and other stakeholders', Sustainability Accounting, Management and Policy Journal Vol. 10(1) (2019), pp. 183-207; Idowu, Samuel O. and Del Baldo, Mara (eds), Integrated Reporting: Antecedents and Perspectives for Organizations and Stakeholders (Cham: Springer, 2019).

50 Integrated Reporting <IR>, 'New Malaysian Corporate Governance Code calls on companies to move towards Integrated Reporting', https://integratedreporting.org/news/new-malaysiancorporate-governance-code-calls-on-companies-to-move-towards-integrated-reporting/.

51 Lorna Patajo-Kapunan, 'New code of corporate governance for publicly listed companies', February 12, 2017, http://www.businessmirror.com.ph/new-code-of-corporate-governance-forpublicly-listed-companies/.

52 See The Institute of Directors in Southern Africa, King IV Report on Corporate Governance for South Africa 2016 (King IV).

53 David Hess, 'Chapter 7: The Future of Sustainability Reporting as a Regulatory Mechanism' in Daniel R. Cahoy and Jamison E. Colburn (eds) Law and the Transition to Business Sustainability (Cham: Springer, 2014) pp. 125 - 139, p. 126.

54 Hess, 'The Future of Sustainability Reporting', p. 126.

55 Jan Bebbington and Ian Thomson, 'Editorial: Sustainable development, management and accounting: Boundary crossing', Management Accounting Research, 24 (2013), 277-283, p. 281. 
has fallen unknown to the accounting world, besides the social and environmental reporting research. ${ }^{56}$

As a comparison to both financial accounting, social and environmental accounting and sustainability accounting frameworks, a novel normative framework, the International Integrated Reporting Council's ${ }^{57}$ (IIRC, previously International Integrated Reporting Committee) International $<I R>$ Framework. ${ }^{58}$ The International $<\mathrm{IR}>$ Framework is said to be something totally different. In the matter of fact, it is not a sustainability report at all, rather, it is a market-led attempt to a different way of thinking about corporate success and reporting. ${ }^{59}$ Whereas a stated aim of sustainability reports like the GRI is to document how organisations impact natural and social environments, the stated aim of $\langle\mathrm{IR}>$ is to provide a concise description of how organisations create value using six types of capital: financial, intellectual, human, social and relationships, manufactured and natural. ${ }^{60}$ Its intended audience is however the providers of financial capital only. ${ }^{61}$ Thus, while <IR> draws concepts like natural capital from sustainability reporting, <IR> adopts its aim and target-audience from mainstream shareholder primacy corporate reporting. ${ }^{62}$ As described by the former CEO of the IIRC, 'IR is a market -led response to the corporate reporting challenges of the twenty-first century. Businesses require an evolution in the system for reporting, facilitating and communicating mega-trends without the complexity and inadequacy of outof-touch reporting requirements., ${ }^{, 63}$

The purpose of this paper is to test (1) what kind of business model, if any, integrated reporting and especially International <IR $>$ Framework represents, (2) what is the impact, if any, of integrated reporting to material corporate governance in the codes it is included in, and (3) if yes, does an integrated view and especially the 'integrated thinking' behind International $<\mathrm{IR}>$ Framework represent a genuine

56 Bebbington and Thomson, 'Editorial', p. 282.

57 http://integratedreporting.org.

58 The International Integrated Reporting Council, The International <IR> Framework, available at http://integratedreporting.org/wp-content/uploads/2015/03/13-12-08-THEINTERNATIONAL-IR-FRAMEWORK-2-1.pdf.

59 The International <IR> Framework, p. 2; Carol A. Adams, 'The International Integrated Reporting Council: A call to action', Critical Perspectives on Accounting, 27 (2015), 23-28, p. 23; Tweedie and Martinov-Bennie, 'Entitlements and Time', 50.

60 Gleeson-White, Six Capitals.

61 The International $<\mathrm{IR}>$ Framework, p. 7.

62 Tweedie and Martinov-Bennie, 'Entitlements and Time', 50; Dale Tweedie, Christian Nielsen and Nonna Martinov-Bennie, 'The Business Model in Integrated Reporting: Evaluating Concept and Application', Australian Accounting Review, 28(3) (2018), 405 - 420, 406.

63 Paul Druckman, 'Foreword' in Chiara Mio (ed) Integrated Reporting: A New Accounting Disclosure (London: Palgrave Macmillan, 2016) pp. v - xi, p. vi. 
sustainable value creation driven business model based on the boundaries of the planet and social foundation for the humanity, or is it only a view to encourage organisations to take care of the profits of the specific non-natural capital providers.

The structure of the rest of the paper is the following. In Section 2 the International $<\mathrm{IR}>$ Framework of the IIRC is presented, including the concepts of integrated thinking and business and their definitions. In Section 3 the concept of business model in integrated thinking and integrated reporting is discussed in detail. In Section 4 the focus is finally set to to integrated thinking as the core concept of governance. In Section 5 the discussion is widened to the uses of integrated reporting in corporate governance. Section 6 is critical by its nature, discussing the reason why integrated reporting (and integrated thinking) is failing as basis of sustainable governance. The paper ends with conclusions in Section 7.

\section{The International < IR > Framework, integrated thinking and business model}

Integrated reporting has rapidly gained considerable prominence since the formation of the IIRC and publication of the International <IR> Framework. ${ }^{64}$ One of the $<\mathrm{IR}>$ Framework's aims is to 'enhance accountability and stewardship for the broad base of capitals (financial, manufactured, intellectual, human, social and relationship (societal), and natural (environmental)) and promote understanding of their interdependencies'. ${ }^{65}$ The Framework is based on an idea of 'shared value creation' by providers of these 'six capitals'. 'Stewardship' means of a responsibility of the organisation to care for, or use responsibly, the capitals that its activities and 'outputs' (products, services, by-products and waste) affect. $^{66}$ As such integrated reporting represents at least in the text level a stakeholder management model already integrated in many corporate governance codes, just broadening the concept of capital providers from the shareholders only to other internal stakeholders providing other capitals to the organisation, by enlarging the goal of capital efficiency and profit maximisation from financial capital only to other five forms of internal capital provisions.

64 de Villiers, Rinaldi and Unerman, 'Integrated Reporting', p. 1043.

65 The International $<\mathrm{IR}>$ Framework, p. 2.

66 The International $<\mathrm{IR}>$ Framework $\mathbf{\Phi} 3.15$. 
The roots, and at the same time, the problems, of integrated reporting in corporate governance are however deeper than in broadening the capital concept in reporting. The integrated report is only the visible part of what is happening below the surface on governance level, described as integrated thinking' and 'integrated decision-making. ${ }^{67}$ The International <IR $>$ Framework emphasises the importance of integrated thinking and its relationship to integrated reporting: 'Integrated thinking is the active consideration by an organization of the relationships between its various operating and functional units and the capitals that the organization uses or affects. ${ }^{68}$

According to the International $<\mathrm{IR}>$ Framework, at the core of an organisation is its 'business model'. ${ }^{69}$ The concept of a 'business model' as used in the Framework represents the way how an organisation creates value, comprising all its activities, its relationships with stakeholders and its tangible and intangible assets and liabilities, and finally the board's responsibilities, as for the board, 'corporate governance' and sustaining and developing the company's business model are essentially the same thing. In the end of the day, it is a question what kind of 'business model' integrated reporting based corporate governance really reflects, and how it possible varies from shareholder-centred business model.

A business model can generally be defined as the organizational and financial 'architecture' of a business' value creation articulating how a firm converts resources and capabilities into economic value, including implicit assumptions about customers, their needs, and the behaviour of revenues, costs and competitors. $^{70}$

At the heart of such a business model is a 'value proposition' that is valuable to both a company's customers and other stakeholders who might otherwise be directly or indirectly affected by a company's activities that can be defined for instance as 'a promise on the economic, environmental and social benefits that a

67 Cecile Churet and Robert G. Eccles, 'Integrated Reporting, Quality of Management, and Financial Performance', Journal of Applied Corporate Finance, 26:1 (2014), 8-16, p. 8.

68 The $<$ IR $>$ Framework, p. 2.

69 The International $<\mathrm{IR}>$ Framework $\mathbb{\Phi}$ 2.23. On role of business model in corporate governance, see Michael Page and Laura F. Spira, 'Corporate governance as custodianship of the business model', Journal of Management \& Governance, 20:2 (2016), 213-228.

70 David J. Teece, 'Business Models, Business Strategy and Innovation', Long Range Planning 43 (2010), 172-194, p. 173; N.M.P. Bocken, S.W. Short, P. Rana and S. Evans, 'A literature and practice review to develop sustainable business model archetypes', Journal of Cleaner Production, 65 (2014), 42-56, p. 43. 
firm's offering delivers to customers and society at large, considering both shortterm profits and long-term sustainability' ${ }^{71}$

\section{Business model in integrated thinking and integrated reporting}

A business model in the International <IR $>$ Framework conceptualization 'draws on various six capitals as inputs and, through its business activities, converts them to outputs'. The activities and the outputs lead to 'outcomes', the internal and external positive and negative consequences for the capitals as a result of the activities and outputs in terms of effects on the capitals. ${ }^{72}$ The business model is an organisation's 'system of transforming inputs, through its business activities, into outputs and outcomes that aims to fulfil the organization's strategic purposes and create value over the short, medium and long term'. ${ }^{73}$ In other words, the business model concept involves (1) the organization's governance, (2) its enterprise risk management (ERM), and (3) its strategy in the short, medium and long term, and (4) its internal controls. The business model impacts on these four aspects while the organization produces a commodity. The commodity in turn impacts on those four aspects. ${ }^{74}$ As the $<\mathrm{IR}>$ aims to combine key financial as well as non-financial aspects in one report, and based upon those 'six capitals', it is intended to show the reciprocal effects between different performance indicators. The capitals, their interrelatedness and their dependencies must be handled according to integrated thinking, the organization's long-term strategy, value creation, performance management and management decision and control, all based on integrated thinking. ${ }^{75}$

71 Samuli Patala, Anne Jalkala, Joona Keränen, Sanni Väisänen, Valtteri Tuominen and Risto Soukka, 'Sustainable value propositions: Framework and implications for technology suppliers' (2016) 59 Industrial Marketing Management 144-156, p. 144; see Florian Lüdeke-Freund, Sarah Carroux, Alexandre Joyce, Lorenzo Massa and Henning Breuer, 'The sustainable business model pattern taxonomy - 45 patterns to support sustainability-oriented business model innovation' Sustainable Production and Consumption, 15 (2018) 145-162, p. 147.

72 The International $<\mathrm{IR}>$ Framework |ा 2.25.

73 The International $<\mathrm{IR}>$ Framework |ा 4.11.

74 Jean J. du Plessis and Andreas Rühmkorf, 'New trends regarding sustainability and integrated reporting for companies: what protection do directors have?', The Company Lawyer, 36 (2015), 49 - 62, p. 49.

75 Judy Oliver, Gillian Vesty and Albie Brooks, 'Conceptualising integrated thinking in practice', Managerial Auditing Journal, 31:2 (2016), 228-248. 
The key to the $<\mathrm{IR}>$ business model concept is the value creation. The $<\mathrm{IR}>$ concept of value creation has changed over time: the original sustainability focus evaporated while the providers of financial capital ('investment supply chain ${ }^{76}$ ) became the targeted users of $\langle\mathrm{IR}\rangle$. The primary purpose of an $\langle\mathrm{IR}>$ is after the transition from stakeholder model to financial capital provider model to explain to (only) the providers of financial capital how an organization creates (them) value over time, ${ }^{77}$ to enable financial capital providers to a more efficient and productive allocation of capital. ${ }^{78}$ Based on this statement it is fair to conclude that <IR $>$ follows a value concept that is embossed by shareholder value. ${ }^{79}$ This investor focus makes the <IR> special; where the primary audience of business model frameworks is almost exclusively management, <IR>'s primarily audience is providers of financial capital. <IR > is atypical in using the business model to communicate externally, rather than primarily as an internal mechanism to focus management's attention on how the business either realises value or innovates. ${ }^{80}$

The $<\mathrm{IR}>$ value concept has two interrelated aspects, value created for (1) the organization itself, which enables financial returns to the providers of financial capital, and for (2) others, that is, stakeholders and society at large. ${ }^{81}$ The value concept expresses a 'fact' (that is in legal terms of course false) 'that in legal terms the organization belongs to and is primarily governed by the financial capital providers. ${ }^{82}$ Due to this investor-centered value concept, investors (the providers of financial capital) are (emphasis here) 'interested in the value an organization creates for itself. They are also interested in the value an organization creates for others when it affects the ability of the organization to create value for itself, or relates to a stated objective of the organization (e. g. an explicit social purpose) that affects their assessments. ${ }^{83}$ The value to others is so subordinated to investor value and the others have value only through it unless otherwise stipulated in the organization's by-laws. So, as a default, the others have only an instrumental value to the investors.

76 Wendy Stubbs and Colin Higgins, 'Stakeholders' Perspectives on the Role of Regulatory Reform in Integrated Reporting', Journal of Business Ethics, 147 (2018), 489-508, p. 496.

77 The International $<\mathrm{IR}>$ Framework, para. 1.7, see also pp. 2 and 4.

78 The International $<\mathrm{IR}>$ Framework, p. 2.

79 Axel Haller, 'Value Creation: A Core Concept of Integrated Reporting' in Chiara Mio (ed) Integrated Reporting: A New Accounting Disclosure (London: Palgrave Macmillan, 2016) pp. 37 57, p. 41.

80 Tweedie, Nielsen and Martinov-Bennie, 'The Business Model', 412.

81 The International <IR $>$ Framework, para. 2.4.

82 Haller, 'Value Creation', p. 44.

83 The International $<\mathrm{IR}>$ Framework, para. 2.5. 
Based on this background, the purpose of $<\mathrm{IR}>$ is take into consideration the financial impact of non-financial issues and so to improve the comprehensiveness of corporate reporting for the shareholder. ${ }^{84}$ For this reason, an increase or a decrease in other capitals than financial capital is irrelevant, unless it is material to the organization's ability to generate returns to providers of financial capital. 'This includes taking account of the extent to which effects on the [other] capitals have been externalized (i. e. the costs or other effects on capitals that are not owned by the organization). ${ }^{85}$ 'Externalities may be positive or negative (i. e. they may result in a net increase or decrease to the value embodied in the capitals). Externalities may ultimately increase or decrease value created for the organization; therefore providers of financial capital need information about material externalities to assess their effects and allocate resources accordingly. ${ }^{86}$

The investor-centrisism of the $<\mathrm{IR}>$ business model reflects however not only the role of the providers of capital but also sets obligations to the management for 'integrated thinking' (see below) on how different capitals connect for the benefit of the providers of financial capital. ${ }^{87}$ This 'integrated thinking' logic suggests that business models should enable managers to re-conceptualise or refocus their organisations' 'value creating activities' and through that, to review their business' key performance indicators or strategies more holistically. ${ }^{88}$

The nature of $<\mathrm{IR}>$ can be understand in the way how it treats humans and nature. ${ }^{89}$ The International <IR> Framework makes a difference between intellectual capital, human and social and relationships capital. 'Intellectual capital' is organizational, knowledge-based intangibles including 'intellectual property such as patents, copyrights, software right sand licences', 'organizational capital' such as 'tacit knowledge, systems, procedures and protocols'. 90 'Human capital' entails people's competencies, capabilities and experience. Human capital as all the other capitals except financial capital is viewed exclusively from the company's and so its institutional investors' viewpoint: humans have no intrinsic value as their value depends on the contribution they make towards corporate success. Humans who are not inputs to the business model have no value.

84 Barker and Kasim, 'Integrated Reporting', p. 95, referring to Sarah Adams and Roger Simnett, 'Integrated Reporting: An Opportunity for Australia's Not-for-Profit Sector', Australian Accounting Review, 21:3 (2011), 292 - 301.

85 The International $<\mathrm{IR}>$ Framework, para. 2.7.

86 The International $<\mathrm{IR}>$ Framework, para. 2.8.

87 See Tweedie, Nielsen and Martinov-Bennie, 'The Business Model', 412.

88 Tweedie, Nielsen and Martinov-Bennie, 'The Business Model', 414.

89 Flower, 'The International Integrated Reporting Council'; de Villiers and Sharma, 'Critical reflection'.

90 International $<\mathrm{IR}>$ Framework, p. 12. 
'Social and relationships capital' is the 'institutions and the relationship with and between communities, groups of stakeholders and other networks, and the ability to share information to enhance individual and collective wellbeing'. 91 'Natural capital' is (emphasis here) 'all renewable and non-renewable environmental resources and processes that provide goods or services that support the past, current or future prosperity of an organization. It includes air, water, land, minerals and forests, biodiversity and eco-system health'. ${ }^{92}$ The essential phrase here is the 'prosperity of an organization'; the International $<\mathrm{IR}>$ Framework is interested only in those elements of the natural capital that are utilized by an organization. ${ }^{93}$ It notes that "many organizations rely on raw materials to ensure production continuity ... Eco-system services such as water purification ... may also feature prominently in the business model. It is important to explain how secure the availability, quality and affordability of these components of natural capital are. 94

All in all, <IR> 'tells a firm's value creation narrative going forward, by specifically referring to corporate strategy, how the strategy translates into a firm's business model and how the business model takes advantage of the six forms of capital to create or destroy value. 'Integrated thinking' is meant to facilitate high-quality IR by promoting a long-term outlook., 95

\section{Integrated thinking in corporate governance}

As mentioned above, the International $<\mathrm{IR}>$ Framework emphasises the importance of integrated thinking within the organization: 'Integrated thinking is active consideration by an organization of the relationships between its various operating and functional units and the capitals that the organization uses or affects. Integrated thinking leads to integrated decision-making and actions that consider the creation of value over the short, medium and long term. ${ }^{96}$

91 International $<\mathrm{IR}>$ Framework, p. 12.

92 International $<\mathrm{IR}>$ Framework, p. 12, para. 2.15. See also Financing a Sustainable European Economy: Final Report, p. 88.

93 de Villiers and Sharma, 'Critical reflection'.

94 The International <IR> Framework, para. 2.28.

95 de Villiers, Venter and Hsiao, 'Integrated reporting', p. 939.

96 The International <IR> Framework, p. 2. 
Integrated thinking has two components. ${ }^{97}$ The first connects strategy, governance, past performance and future prospects through which an organisation takes into account the connectivity and interdependencies between the factors that have a material effect on its ability to create value over time. These include the capacity of the organisation's governance structure to respond to stakeholder needs, interests and expectations as well as the capitals it uses, and affects, and the critical interdependencies, including trade-offs, between them. ${ }^{98}$

The second aspect of integrated thinking connects the organisation's various internal departments. The process of producing an integrated report explores the relationships between a company's various internal units to provide a deeper and better understanding of its internal processes and relationships. ${ }^{99}$ Integrated thinking takes into account the connectivity and interdependencies between the capitals and critical interdependencies between them, the capacity of the organization to respond to key stakeholders' legitimate needs and interests, how the organization tailors its business model and strategy to respond to its external environment and the risks and opportunities it faces, the organization's activities, financial and other performance and outcomes in terms of the capitals - past, present and future. ${ }^{100}$

The role of integrated thinking to understand an organization's business model in integrated reporting can be understood when we look the role of corporate reporting in corporate governance. The Cadbury Committee itself was tasked firstly simply to deal with the financial aspects of corporate governance. One crucial reason for the Cadbury Report was flaws in the quality of corporate reporting. ${ }^{101}$ According to the Report itself, the code was motivated by 'the perceived low level of confidence both in financial reporting and in the ability of auditors to provide the safeguards which the users of company reports sought and expected. The underlying factors were seen as the looseness of accounting standards, the absence of a clear framework for ensuring that directors kept under review the controls in their business, and competitive pressures both on

97 John Dumay and Tim Dai, 'Integrated thinking as a cultural control?', Meditari Accountancy Research, $25: 4$ (2017), 574 - 604, pp. 577 - 578.

98 International Integrated Reporting Council, Consultation Draft of the International <IR> Framework, International Integrated Reporting Council, London, April 2013, p. 9, http://integrate dreporting.org/wp-content/uploads/2013/03/Consultation-Draft-of-the-InternationalIRFramework. pdf.

99 Dumay and Dai, 'Integrated thinking', pp. 577 - 578.

100 The International $<\mathrm{IR}>$ Framework, p. 2.

101 Ruth V. Aguilera and Alvaro Cuervo-Cazurra, 'Codes of Good Governance Worldwide: What is the Trigger?’, Organization Studies, 25:3 (2004), 417-446, p. 421. 
companies and on auditors which made it difficult for auditors to stand up to demanding boards.'102

After Cadbury Committee, the scope of corporate governance codes has expanded considerably. ${ }^{103}$ In the 1990s it was thought that globalisation of financial systems causes a convergence of corporate governance systems towards the Anglo-American model because it was based on stock market principles. ${ }^{104}$ Increasing demands for corporate responsibility have however lead to an emerging trend towards a more stakeholder-orientated view of the corporation also in Anglo-American countries, certainly in the United Kingdom and Australia. ${ }^{105}$ Finally, the South African 'King thinking' is based on the idea that the modern approach of management is one of an integrated thinking. ${ }^{106}$ South African model integrated thinking management takes into account all six capitals the organisations uses, transforms and provides. An integrated report is just the outcome of integrated thinking; according to the latest King IV Report, '[i]ntegrated thinking is defined as the active consideration by an organization of the relationships between its various operating and functional units and the capitals that the organization uses or affects. ${ }^{107}$

The integrated thinking in the Framework and the King reports can be compared with the idea of 'integrated governance' proposed for instance by the United Nations Environment Programme Finance Initiative (UNEP FI). ${ }^{108}$ Unlike integrated thinking, integrated governance is purported as a model that 'moves

102 Cadbury Report 1 2.1.

103 J. du Plessis and Chee Keong Low, 'Corporate Governance Codes Under the Spotlight' in Jean J. du Plessis and Chee Keong Low (eds), Corporate Governance Codes for the twenty-first Century: International Perspectives and Critical Analyses (Cham: Springer, 2017) pp. 3-20, p. 256. 104 Mauro F. Guillén, 'Corporate Governance and Globalization: Is There Convergence Across Countries?' in Thomas Clarke (ed), Theories of Corporate Governance: The philosophical foundations of corporate governance (London \& New York: Routledge, 2004) pp. 223-242.

105 Alice Klettner, Thomas Clarke and Martijn Boersma, 'The Governance of Corporate Sustainability: Empirical Insights into the Development, Leadership and Implementation of Responsible Business Strategy', Journal of Business Ethics, 122 (2014), 145-165, p. 149.

106 Irene-Marie Esser, 'Corporate Governance: Soft Law Regulation and Disclosure - The Cases of the United Kingdom and South Africa' in Jean J. du Plessis and Chee Keong Low (eds), Corporate Governance Codes for the twenty-first Century: International Perspectives and Critical Analyses (Cham: Springer, 2017) pp. 233-260, p. 256.

107 King IV Report, p. 13.

108 United Nations Environment Programme, Integrated Governance: A new model of governance for sustainability. A report by the Asset Management Working Group of the United Nations Environment Programme Finance Initiative, June 2014. 
sustainability issues from the periphery of corporate strategy to the heart of it $^{109}$, or to move from 'governance for sustainability' to an integrated governance perspective. ${ }^{110}$ Integrated governance tries to answer the question 'If current governance practices are ineffective in promoting a culture of sustainability, then what is the alternative?'111 In integrated governance, sustainability issues are integrated in a way that ensures value creation for the company and beneficial results for all stakeholders in the long term, to ensure the management of all types of capital. ${ }^{112}$ Integrated governance requires oversight of a sustainable strategy by the board so that sustainability risks and opportunities are seamlessly part of the strategic agenda for the firms, and integrated reporting is used as the means to measure progress in both financial and non-financial targets. ${ }^{113}$

The most recent signal of integrated governance is the European Commission's initiative on Sustainable Finance, signalling a willingness to ensure a deeper integration of corporate sustainability into the regulation of business and finance. ${ }^{114}$ The appointment of the EU High-Level Expert Group on Sustainable Finance was intended to be a first step towards a EU sustainable finance strategy. The Group's objective was to help to develop an overarching and comprehensive EU strategy on sustainable finance to integrate sustainability into EU financial policy. ${ }^{115}$

In its interim report from July 2017, the High-Level Expert Group advocated strongly the integration of sustainability into the duties of the board and management, combined with clear and comprehensive reporting. The central challenges for the Group were three-fold; first to identify more precisely the core areas of sustainability by outlining an initial framework on sustainability taxonomy, standards and labels, secondly to foster longer-term orientation in finance and the wider economy by exploring ways to attenuate impatience in finance and avoid decision-making, in particular regarding investments, based on too short horizons, and thirdly to integrate environmental, social and governance factors into financial decision-making by examining key elements across the investment and lending chain. ${ }^{116}$ In its

109 Integrated Governance, p. 5.

110 Integrated Governance, p. 35.

111 Integrated Governance, p. 35.

112 Integrated Governance, p. 35.

113 Integrated Governance, p. 36.

114 See www.ec.europa.eu/info/business-economy-euro/banking-and-finance/sustainablefinance_en.

115 Financing a Sustainable European Economy: Interim Report, p. 5.

116 Financing a Sustainable European Economy: Interim Report, p. 3. 
final report from January 2017, the Group repeated its proposal to adopt minimum ESG 'stewardship standards' for investment mandates covering all asset classes and applicable to all institutions in the investment chain that act on behalf of others. ${ }^{117}$

Important part of the Group's idea of integrated governance is to a single set of principles of fiduciary duty and related concepts of loyalty and prudence in which 'consideration and management of ESG risks [and long-term sustainability] is integral to fulfilling fiduciary duty, acting loyally to beneficiaries and operating in a prudent manner', instead of a 'misinterpretation of fiduciary duty as requiring a focus solely on maximising short-term financial returns'. ${ }^{118}$ In practice this means that material environmental, social and governance factors should be integrated into the national definitions of fiduciary duties, either directly or through EU legislation. ${ }^{119}$

The remaining question is of course how to establish this kind of single set of principles of fiduciary duty and related concepts of loyalty and prudence. ${ }^{120}$ Reporting is an integral part of integrated governance, but it is not enough. Albeit the Group acknowledged the efforts made by many European firms to strengthen transparency on environmental, social and governance factors and to improve reporting quality, comparability and relevance generally, high quality integrated reporting remains far from being mainstream. ${ }^{121}$ While there are numerous initiatives on sustainability reporting, the ultimate ambition has to be the convergence of financial and sustainability information, supported by a more comprehensive set of accounting standards. According to the Group, integrated reporting supports this convergence qualitatively through reporting that links sustainability factors with firms' strategy. Accounting standards can help advance the quantitative element. ${ }^{122}$ The Group urges to examine how to foster integrated reporting and integration of financial and non-financial/sustainability issues into reporting. ${ }^{123}$

117 Financing a Sustainable European Economy: Final Report, p. 38.

118 Financing a Sustainable European Economy: Interim Report, p. 57; see also High-Level Expert Group on Sustainable Finance, Financing a Sustainable European Economy: Final Report (January 2018), p. 39, https://ec.europa.eu/info/sites/info/files/180131-sustainablefinance-final-report_en.pdf.

119 See Financing a Sustainable European Economy: Final Report, p. 62.

120 Financing a Sustainable European Economy: Interim Report, p. 57.

121 Financing a Sustainable European Economy: Interim Report, p. 57.

122 Financing a Sustainable European Economy: Interim Report, p. 29; Financing a Sustainable European Economy: Final Report, p. 56.

123 Financing a Sustainable European Economy: Interim Report, p. 61. 
In its Sustainable Finance Action Plan, ${ }^{124}$ there is not however a thread on integrated reporting, albeit it is recognised (in a footnote) that governance is a tool to integrate environmental and social objectives in public and private investment decisions. However, the examples are traditionally shareholdercentred, as executive compensation rules or incentives to protect shareholders' rights from managers. ${ }^{125}$ However, Action 7 of the plan mentions the fiduciary duties, promising a legislative proposal to clarify institutional investors' and asset managers' duties in relation to sustainability considerations. The proposal, aimed to the end of 2018, is to (i) explicitly require institutional investors and asset managers to integrate sustainability considerations in the investment decision-making process and (ii) increase transparency towards end-investors on how they integrate such sustainability factors in their investment decisions, in particular as concerns their exposure to sustainability risks. ${ }^{126}$ Neither the Commission proposal from May 2018 nor the final Regulation from October 2019 refer to integrated reporting, however. ${ }^{127}$

More than reporting is however required to establish a true integrated governance. Considering integrated thinking as basis for integrated governance, it is true that integrated thinking requires a business to reconsider the short, medium and long term sustainability of the entity. ${ }^{128}$ In $<$ IR $>$ it would require that the firm should report on all the capitals that are affected by its activities. ${ }^{129}$ The <IR> Framework does

124 Communication from the Commission to the European Parliament, the European Council, the Council, the European Central Bank, the European Economic and Social Committee and the Committee of the Regions, Action Plan: Financing Sustainable Growth, 8.3.2018, COM/2018/097 final.

125 Action Plan, p. 2 fn. 9.

126 Action Plan, p. 8-9.

127 European Commission, Proposal for a Regulation of the European Parliament and of the Council on disclosures relating to sustainable investments and sustainability risks and amending Directive (EU) 2016/2341, 24.5.2018, $\operatorname{COM(2018)~} 354$ final.; Regulation of the European Parliament and of the Council on sustainability-related disclosures in the financial services sector (Text with EEA relevance), PE-CONS 87/19, https://data.consilium.europa.eu/doc/document/PE-87-2019-INIT/en/pdf.

128 Esser, 'Corporate Governance: Soft Law Regulation and Disclosure’, p. 257.

129 John Flower, 'The International Integrated Reporting Council: A story of failure', Critical Perspectives on Accounting, 27 (2015), 1-17, p. 6; see also Carol A. Adams, 'The International Integrated Reporting Council: A call to action', Critical Perspectives on Accounting, 27 (2015) 2328; Ian Thomson, "But does sustainability need capitalism or an integrated report' a commentary on 'The International Integrated Reporting Council: A story of failure' by Flower, J.', Critical Perspectives on Accounting, 27 (2015), 18-22; Michelle Rodrigue, 'The International Integrated Reporting Council: A Story of Failure; 'But Does Sustainability need Capitalism or an Integrated Report' a Commentary on 'The International Integrated Reporting Council: A Story of Failure' by Flower, J.; The International Integrated Reporting Council: A Call to Action', Social and Environmental Accountability Journal, 35:2 (2015), Economic Democracy and Accounting. 
however the vice versa as capitals are reported only if they provide value to the firm and its providers of financial capital. If the firm causes externalities, decreasing the value of the capitals outside the organisation, they are not reported. So, the Framework is ignorant to damage caused by the firm to capitals (for instance to ecosystem, infrastructure and people through pollution emitted) if the damage does not affect the firm's production process (infrastructure, raw materials and people in the firm's service). ${ }^{130}$ The Framework accepts so that the integrated report should cover the impact of the capitals on the firm, but ignores the firm's impact (causing externalities) on these capitals.

Problem of the $<\mathrm{IR}>$ Framework is so that it does not follow integrated thinking in the end. As all kinds of 'CSR' and 'sustainability' reports are targeted to the classical 'stakeholders', the <IR> addresses (institutional) investors both in equity and debt ('investment supply chain'131), 'providers of financial capital to enable a more efficient and productive allocation of capital'. ${ }^{132}$ As stated in the Framework itself, the 'primary purpose of an integrated report is to explain to providers of financial capital how an organization creates value over time. It therefore contains relevant information, both financial and other' (emphasis added). ${ }^{133}$ An integrated report only 'benefits all stakeholders interested in an organization's ability to create value over time, including employees, customers, suppliers, business partners, local communities, legislators, regulators and policy-makers'. ${ }^{134}$

\section{Use of integrated reporting in corporate governance}

The aim of $<\mathrm{IR}>$ is to get managers and providers of financial capital to consider the long-term consequences of a broader set of capitals. ${ }^{135}$ The investor-centrism of $<\mathrm{IR}>$ helps the management to avoid a conflict of objectives arising from the consideration of heterogeneous target groups. ${ }^{136}$ On the other hand, <IR> is

130 Flower, 'The International Integrated Reporting Council', pp. 6-7.

131 Wendy Stubbs and Colin Higgins, 'Stakeholders' Perspectives on the Role of Regulatory Reform in Integrated Reporting', Journal of Business Ethics, 147 (2018), 489-508, p. 496.

132 The International <IR $>$ Framework, p. 2.

133 The $<\mathrm{IR}>$ Framework |ा 1.7.

134 The $\langle\mathrm{IR}>$ Framework Iा 1.8.

135 Charl de Villiers, Elmar R. Venter and Pei-Chi Kelly Hsiao, 'Integrated reporting: background, measurement issues, approaches and an agenda for future research', Accounting \& Finance, 57 (2017), 937-959, p. 939.

136 Velte and Stawinoga, 'Integrated reporting', p. 278. 
focused on helping investors identify those social and environmental issues that are material from an investor's perspective, and creating the 'business case' for the consideration of ESG issues, which it believes will cause managers within the corporation to take these issues more seriously and then seek to improve performance. $^{137}$

Using Humphrey's, O’Dwyer's and Unerman's expression, the target group was the 'long-term enlightened investor' and so, the 'enlightened shareholder' logic. ${ }^{138}$ As investors decide on an entity's business model, strategies and decisions taken because they appoint and dismiss the board and 'decide on the provision of cash, which is the 'fuel' that is needed to keep the entity running'. Through this decisive power position investors have a key role for the value concept applied in the management's strategies and decisions, whether it includes just one sort of capital or whether it is more comprehensive. ${ }^{139}$ In this form, <IR> sits well in modern shareholder primacy corporate governance.

The most relevant usage of integrated reporting in corporate governance is the South African corporate governance codes, the King reports. In the South African 'King tradition', considerations of sustainability are 'at the heart of the leadership and governance role of the board' ${ }^{140}$ connecting sustainability to the Brundtland Report definition ('meeting the needs of the present generation without compromising the ability of future generations to meet their needs'), ${ }^{141}$ the UN Sustainable Development Goals and the 'six capitals' of the IIRC. The King tradition connected integrated reporting to the South African Constitution imposing responsibilities upon individuals and juristic persons for the realisation of the most fundamental rights, ${ }^{142}$ reflecting the uniquely African form of communitarianism embodied in the concept of 'Ubuntu'. ${ }^{143}$ Companies were seen as citizens of the South African community with a consequent ethical responsibility to disclose their impacts on 'other' South African citizens. ${ }^{144}$

137 Hess, 'The Future of Sustainability Reporting', p. 131.

138 Christopher Humphrey, Brendan O'Dwyer and Jeffrey Unerman, 'Re-theorizing the configuration of organizational fields: the IIRC and the pursuit of 'Enlightened' corporate reporting', Accounting and Business Research, 47:1 (2017), 30 - 63, p. 53, 44.

139 Haller, 'Value Creation', p. 51 - 52.

140 Ansie Ramalho, The link between codes of corporate governance and sustainability, on file with author.

141 World Commission on Environment and Development, Our Common Future (Oxford University Press, 1987), p. 15.

142 Institute of Directors in South Africa, King Code of Governance South Africa 2009 (King III), p. 10.

143 King III, p. 61.

144 Tweedie and Martinov-Bennie, 'Entitlements and Time', 54. 
The King tradition view to governance differed drastically from the IIRC's. Albeit according to one of the Guiding Principles of the International <IR $>$ Framework an $<\mathrm{IR}>$ 'should provide insight into the nature and quality of the organization's relationships with its key stakeholders, including how and to what extent the organization understands, takes into account and responds to their legitimate needs and interests', ${ }^{145}$ the Framework requires each organisation to explain how its 'governance structure support[s] its ability to create value in the short, medium and long term', viewing governance as a cog in the value-creation process. ${ }^{146}$ By contrast, the King tradition defined governance as about values (i. e. ethics) rather than value-creation: 'Good governance is essentially about effective leadership. Leaders should rise to the challenges of modern governance. Such leadership is characterized by the ethical values of responsibility, accountability, fairness and transparency." "147 The practical implication of these principles was that changes in non-financial capital that impact stakeholders may be material to IR even if they have no long-term effect on financial capital. For instance, if safety at work is a fundamental right, then it is ipso facto material irrespective of its impact on financial value. ${ }^{148}$ The King tradition took integrated thinking seriously: enhancing all forms of capital represented the creation of value and depleting them constituted destruction of value. ${ }^{149}$

The most recent King IV Report uses both the six capitals model and reference to an integrated economic, social and environmental context within which corporations operate as lenses through which to view sustainable development, to expand their view of success and redefine it in terms of long-term, positive outcomes for business, society and the environment. According to King IV an organisation is a part of society in its own right. ${ }^{150}$ It does not exist in its own narrow universe of internal stakeholders within its value chain. In King IV there is a focus on reporting in an integrated manner across the dimensions of the economy, society and the natural environment and disclosure as essential for market and societal accountability mechanisms to operate. ${ }^{151}$ Indeed, the focus in King IV is not anymore in the integrated reporting itself but in integrated thinking. Many in South Africa believe that adopting integrated thinking throughout the business is more critical than preparing the annual integrated report. Investors look for integrated thinking in the companies they invest in; it shows that the board and management are aware of all the capitals needed to ensure the ongoing

145 The International <IR $>$ Framework, p. 5.

146 The International <IR> Framework, p. 25; Tweedie and Martinov-Bennie, 'Entitlements and Time', 55.

147 King III, p. 9; Tweedie and Martinov-Bennie, 'Entitlements and Time', 55.

148 Tweedie and Martinov-Bennie, 'Entitlements and Time’, 54.

149 Ramalho, 'The link between'.

150 King IV, p. 4.

151 Ramalho, 'The link between'. 
viability of the business. The board will set or approve the company's strategic objectives only after considering all the capitals important to the viability of the business. Management will implement these objectives throughout the company and ensure that the staff recognise their importance. ${ }^{152}$

Albeit King IV Report references the International <IR $>$ Framework underpinned by the same thinking and terminology, ${ }^{153}$ it is not an integral part of the Report. As before, there is not a requirement to use of the Framework. The Integrated Reporting Committee of South Africa ${ }^{154}$ has only endorsed the $<\mathrm{IR}>$ as 'good practice on how to prepare an integrated report' but it is the substance of the report - referred to in King IV Report as an 'outcomes-based approach' - that is important, not its form. ${ }^{155}$ The outcomes-based approach determines that companies in South Africa may prepare an integrated report in any form they choose as long as they demonstrate compliance with all of the King IV governance principles on an 'apply and explain basis, and this does not explicitly demand or necessitate the $<\mathrm{IR}>$. ${ }^{156}$

Another example using integrated reporting as part of its corporate governance code is Malaysia. According to the revised Malaysian Code of Corporate Governance $^{157}$ large companies ${ }^{158}$ are encouraged to adopt integrated reporting based on a globally recognised framework. ${ }^{159}$ As stated in the Code, an 'integrated report is the main report from which all other detailed information flows; such as annual financial statements, governance and sustainability reports. It is concise

152 Leigh Georgia Roberts, 'Integrated Reporting: The South African Experience', The CPA Journal: The Voice of the Profession, July 2017, p. 12.

153 International Integrated Reporting Council, IRC of South Africa: Integrated Reporting is a key feature of King IV, November 2, 2016, http://integratedreporting.org/news/irc-of-southafrica-integrated-reporting-is-a-key-feature-of-king-iv/.

154 Integrated Reporting Committee of South Africa, www.integratedreportingsa.org, Guidance in South Africa, http://integratedreportingsa.org/integrated-reporting/guidance/.

155 King IV, p. 7.

156 John Dumay, Cristiana Bernardi, James Guthrie and Matteo La Torre, 'Barriers to Implementing the International Integrated Reporting Framework: A Contemporary Academic Perspective', Meditari Accountancy Research, 25(4) (2017), 461-480.

157 Securities Commission Malaysia, Malaysian Code on Corporate Governance (2017), https:// www.sc.com.my/api/documentms/download.ashx?id=70a5568b-1937-4d2b-8cbf-3aefed112c0a.

158 Under the Malaysian Code on Corporate Governance (p. 3, para. 2.6) large companies are companies on the FTSE Bursa Malaysia Top 100 Index; or companies with market capitalisation of RM2 billion and above, at the start of the companies' financial year. Once a company is under the category of large companies, it will remain as one for the entire financial year regardless of the change in its status during the financial year.

159 Malaysian Code on Corporate Governance, p. 45, Practice para. 11.2. On the Malaysian Code on Corporate Governance see Sejati, Yuyun A. and Jones, Christopher R., 'The Impact of Malaysian Code on Corporate Governance and Political Connections on Accounting Conservatism', Journal of Accounting and Finance 19(3) (2019), pp. 115-132. 
communication about how a company's strategy, performance, governance and prospects lead to value creation. An integrated report improves the quality of information available to investors and promotes greater transparency and accountability on the part of the company. The preparation of this report requires integrated thinking of the relationship between its various operating and functional units, thus breaking down internal silos and reducing duplication., 160

Unlike in South African King Code, the reference in the Malaysian Code is directly to International <IR> Framework. ${ }^{161}$ However, the use of integrated reporting is only encouraged, and so not under the Code's 'apply or explain,162 requirement. Implementation of integrated reporting is still low, $5 \%$ of top 100 companies by revenue in Malaysia in 2017. ${ }^{163}$ If International <IR> Framework is to be implemented efficiently, then it should be driven by regulation, being either fully mandatory or on an 'apply or explain' basis. ${ }^{164}$

\section{Why integrated reporting is failing?}

The problems $<\mathrm{IR}>$ is to solve in financial reporting are real: (1) complexity, (2) lack of connectivity, and (2) lack of forward-looking information. ${ }^{165}$ In the last

160 Malaysian Code on Corporate Governance, p. 46, Guidance para. 11.2.

161 Interntional Integrated Reporting Council, New Malaysian Corporate Governance Code calls on companies to move towards Integrated Reporting, April 26, 2017, https://integratedreporting. org/news/new-malaysian-corporate-governance-code-calls-on-companies-to-move-towards-inte grated-reporting/.

162 Malaysian Code on Corporate Governance, p. 8, para. 5.2.

163 KPMG: Malaysia's Top 100 leads sustainability reporting practices, Borneo Post Online, October 25, 2018, https://www.theborneopost.com/2017/10/25/kpmg-malaysias-top-100-leadssustainability-reporting-practices/; Jalila Johari and Komathy, 'Sustainability reporting and firm performance: evidence in Malaysia', International Journal of Accounting, Finance and Business 4 (17) (2019), 32-45, p. 36. See also The MIA-ACCA Integrated Reporting Survey 2015, see 'An MIA-ACCA report sheds light on IR in Malaysia: Malaysian companies are eager to gain knowledge about integrated reporting and how it can benefit the organisation and its stakeholders, says a new MIA-ACCA report', ACCA Think Ahead, November 1, 2016; Jaffar, Nahariah, Nor, Azleen Shabrina Mohd, Selamat, Zarehan, 'Analysis of Voluntary Disclosure Before and After the Establishment of the Integrated Reporting Framework', Accounting and Finance Review 3(4) (2018), pp. 105-113, p. 106; Adhariani and de Villiers, 'Integrated reporting', p. 184.

164 Jaffar, Nor and Selamat, 'Analysis', p. 108; Adhariani and de Villiers, 'Integrated reporting', p. 199 (referring to surveys both in Malaysia and Indonesia).

165 Carlo Marcon and Moreno Mancin, 'Empirical Evidence on Current Integrated Reporting Practices' in Chiara Mio (ed) Integrated Reporting: A New Accounting Disclosure (London: Palgrave Macmillan, 2016) pp. 59-80, p. 60. 
few decades, financial reporting has become steadily more complex and financial reports longer. New and extensive reporting requirements and more and more complex financial reporting standards as the IFRS have caused information overload, making it increasingly difficult for users to extract the relevant information they need. It is also clear there is not enough non-financial information in traditional reports, and if there is, it is not adequately linked with the financial information. Statutory financial statements, management commentaries, corporate governance reports and 'corporate social responsibility' and 'sustainability' reports form isolated parts within annual reporting or even published separately. Finally, traditional corporate reporting lacks forward-looking information and provides limited usefulness in predicting the long-term performance of an organization.

The International Integrated Reporting Council expresses as its 'long term vision is a world in which integrated thinking is embedded within mainstream business practice in the public and private sectors, facilitated by Integrated Reporting $(<\mathrm{IR}>)$ as the corporate reporting norm. The cycle of integrated thinking and reporting, resulting in efficient and productive capital allocation, will act as a force for financial stability and sustainability' ${ }^{166}$ There is however only one reference to sustainability in the <IR $>$ Framework itself, which is to a separate sustainability report that is not part of the integrated report. ${ }^{167}$ Indeed, it is not the Framework's purpose at all to address sustainability. ${ }^{168}$

Ignoring sustainability in the <IR $>$ Framework is not a surprise, as the Framework makes clear that the principal function of integrated reporting is the reporting of 'value' to the financial investors; as stated in the Framework, the 'primary purpose of an integrated report to explain to providers of financial capital how an organization creates value over time', ${ }^{169}$ not value to the environment and society, or not even to 'stakeholders', nor 'present and future generations'. The primary purpose of an integrated report is to explain the firm's value creation to financial investors and hence 'value' has to be interpreted according to their interests. ${ }^{170}$ As stated in the Framework, financial investors 'are interested in the value an organization creates for

166 The $<$ IR $>$ Framework, p. 2.

167 The $<\mathrm{IR}>$ Framework |ा 1.13.

168 Adams, 'The International Integrated Reporting Council'; see also Markus J. Milne and Rob Gray, 'W(h)ither ecology? The triple bottom line, the global reporting initiative, and corporate sustainability reporting', Journal of Business Ethics, 118:1 (2013), 13-29, p. 20; Monciardini, Dumay and Biondi, 'Integrated Reporting', p. 8.

169 The <IR> Framework |ा 1.7.

170 John Flower, 'The International Integrated Reporting Council: A story of failure', Critical Perspectives on Accounting, 27 (2015), 1-17, p. 5. 
itself. They are also interested in the value an organization creates for others when it affects the ability of the organization to create value for itself (emphasis added). ${ }^{171}$ Taking to consideration the purpose of the Framework, 'value for itself' should be interpreted as 'value for investors'. ${ }^{172}$ The Framework accepts that providers of financial capital are principally interested in the benefits that they can expect from the firm, referring in specifically to 'financial returns to the providers of financial capital' ${ }^{173}$ From a firm's viewpoint, other capitals than financial capital have value only in so far as they contribute to the firm's value. The Framework's investor orientation essentially determines the content of the integrated report. ${ }^{174}$

This is reflected in practice. According to an empirical research by Ahmed Haji and Hossain in South Africa, companies follow more and more the 'multiple capital framework' language with cursory use of specific $<\mathrm{IR}>$ terms, recognising that the multiple capitals are increased, decreased and/or transformed through organisational activities, and that there are potential trade-offs between multiple capitals, or components of a capital. ${ }^{175}$ In this sense, the <IR $>$ has reached weak sustainability level. The content of the reported information is however generic, often vague, and lacks contextual meaning and substance. The discussions on multiple capitals are largely limited to integrated reports, with companies hardly making references to the interdependencies and trade-offs between the capitals in other organisational reporting channels. The adoption of the $<\mathrm{IR}>$ does not so necessarily mean adoption of 'integrated thinking'. Companies use in their reports without constraints rhetorical language to exaggerate positive outcomes while underplaying, even dismissing, negative comparisons and trends. ${ }^{176}$

171 The $<$ IR $>$ Framework |ा 2.5.

172 Flower, 'The International Integrated Reporting Council', p. 6.

173 The <IR> Framework II 2.4.

174 Flower, 'The International Integrated Reporting Council', p. 6.

175 Abdifatah Ahmed Haji and Dewan Mahboob Hossain, 'Exploring the implications of integrated reporting on organisational reporting practice: Evidence from highly regarded integrated reporters', Qualitative Research in Accounting \& Management, 13(4) (2016), 415 - 444, 439.

176 Abdifatah Ahmed Haji and Dewan Mahboob Hossain, 'Exploring the implications of integrated reporting on organisational reporting practice: Evidence from highly regarded integrated reporters', Qualitative Research in Accounting \& Management, 13(4) (2016), 415 - 444, 439. 


\section{Conclusion}

The answer to the first research question, what kind of stakeholder model, if any, integrated reporting and especially International $\langle\mathrm{IR}\rangle$ Framework represents, is that it reflects an 'enlightened' version of shareholder primacy, not any stakeholder model as such. The Framework is investor oriented and the role of the stakeholders, as providers of non-financial capitals, are seen through the value their capitals generate to the providers of financial capital. There is so a clear resemblance between the <IR> Framework and section 172 of the UK Companies Act 2006. ${ }^{177}$ According to section 172 company directors are required 'to promote the success of the company for the benefit of its members [shareholders] as a whole' while the Framework's objective is that a firm should maximize its long-term value, value being interpreted as 'value for itself'. ${ }^{178}$ Section 172 lists a number of factors that directors should regard in promoting the company's success, including the long term consequences of their decisions, the interests of employees, the need to foster the company's business relationships with suppliers, customers and others, the impact on the community and the environment and the need to maintain a reputation for high standards of business conduct, all mentioned as important also in the Framework, as contributing to the long term success of the organization. Both the Framework and the Companies Act adopt the same approach: the firm should maximize longterm value for shareholders, and, to achieve this, it should have proper regard for the interest of others. ${ }^{179}$

As section 172 of Companies Act, is the Framework as a safeguard of environmental and social interests illusory. Both prioritise financial investors' interests over stakeholders' interests. Additionally, the mode of regulation in either of the framework do not provide substantive content to integrated thinking with the visibility that is necessary for it to be functionally a viable way of stakeholders' featuring in corporate decision-making as a matter of best practice. ${ }^{180}$ As section 172 of Companies Act, also the Framework gives the illusion that something is being done to acknowledge stakeholders' interests in corporate decision-making.

177 On section 172, see Georgina Tsagas, 'Section 172 of the Companies Act 2006: Desperate times call for soft law measures' in Nina Boeger and Charlotte Villiers (eds), Shaping the Corporate Landscape: Towards Corporate Reform and Enterprise Diversity (Hart Publishing, 2018), pp. 131-150.

178 Flower, 'The International Integrated Reporting Council', p. 9.

179 Flower, 'The International Integrated Reporting Council', p. 9.

180 Tsagas, 'Section 172'. 
Based on this, the answer to the second research question, what is the impact, if any, of integrated reporting to material corporate governance in the codes it is included in, is that the integrated thinking behind integrated reporting strengthens the shareholder primacy ideology behind the codes more than weakens it. However, the South African King IV Code and its unique conception of integrated thinking is an exception and brings hope to those seeing integrated thinking and reporting as a path to sustainable governance. So far, when thinking the Framework as a whole, the answer to the third research question, does an integrated view and especially the 'integrated thinking' behind International <IR $>$ Framework represent a genuine sustainable value creation driven business model based on the boundaries of the planet and social foundation for the humanity, or is it only a view to encourage organisations to take care of the profits of the specific capital providers, is the latter.

The most important question is however what is the future path of the <IR> Framework. ${ }^{181}$ The key is in integrated thinking itself. Genuine sustainable change depends on the extent to which integrated thinking can confront, challenge and colonise the 'unintegrated thinking' that dominates contemporary business governing. ${ }^{182}$ It is also crucial for a revised thinking in shareholder primacy based corporate governance codes, referring more to integrated thinking and reporting. Investors are crucial in integrated thinking both by appointing managers that are willing and able to apply integrated thinking and applying integrated thinking themselves in their capital allocation decisions, not to forget however all other participants in investment supply chains and market institutions as stock exchanges. ${ }^{183}$ The concept of <IR> alone is not intended to and cannot reach change in thinking in investment supply chain itself. Integrated thinking has however potential to be an important piece in corporate sustainability. In this respect and in this respect alone, the IIRC is right in expressing its expectation that 'the cycle of integrated thinking and reporting, resulting in efficient and productive capital allocation, will act as a force for financial stability and sustainability'. ${ }^{184}$

Nevertheless, <IR> might develop as a key information instrument for all stakeholders, not only for shareholders, and might replace CSR reporting in the

181 See Monciardini, Dumay and Biondi, 'Integrated Reporting', pp. 14-15.

182 Thomson, 'But does sustainability need capitalism', p. 21.

183 Haller, 'Value Creation', p. 52.

184 The International <IR> Framework, p. 2; see Haller, 'Value Creation', p. 53. 
long run. $<\mathrm{IR}>$ focuses on value creation through the lens of the six capitals rather than CSR or sustainability reporting's focus on environmental and social impacts through the lens of stakeholder materiality. ${ }^{185}<\mathrm{IR}>$ 'draws on different reporting strands and communicates the full range of factors that materially affect the ability of an organization to create value over time', enhancing 'accountability and stewardship for the broad base of capitals ... and promote understanding of their interdependencies. ${ }^{186}$ It is however seen as a preserver of status quo; it is seen as storytelling and meeting institutional expectations, not to encourage innovations in reporting processes nor change to corporate norms. $^{187}$

$<\mathrm{IR}>$ is however right on stakeholders. With focus on capitals and business models, it is pointless to focus on stakeholders as the same stakeholder has an impact on different capitals. ${ }^{188}$ In current society, the same person can simultaneously be the customer, employee and shareholder of the same company and, in such a context, the stakeholder- based classifications become less relevant. ${ }^{189}$ So clearly the benefit of $<\mathrm{IR}>$ is in its business model innovation. ${ }^{190}$ The danger is that business model remains as marketing information. ${ }^{191}$ Even bigger danger is that it is more an obstacle than driver for corporate governance code reforms.

In the end of the day the question is, is <IR> too deeply rooted in the business case for sustainability to make a sustainability case for business? ${ }^{192}$

Acknowledgements: This research is part of Sustainable Market Actors for Responsible Trade (SMART) project. SMART (2016-2020) receives funding from the European Union's Horizon 2020 research and innovation programme under Grant Agreement No 693642. My warmest thanks to the SMART team for inspiring discussions.

185 Stubbs and Higgins, 'Stakeholders' Perspectives', p. 490.

186 International $<\mathrm{IR}>$ Framework, p. 2.

187 Colin Higgins, Wendy Stubbs and Tyron Love, 'Walking the talk(s): Organisational narratives of integrated reporting', Accounting, Auditing \& Accountability Journal, $27: 7$ (2014), 1090 1119; de Villiers, Venter and Hsiao, 'Integrated reporting', p. 943.

188 Mio, 'Integrated Reporting', p. 9.

189 Mio, 'Integrated Reporting', p. 17.

190 Epameinondas Katsikas, Francesca Manes Rossi and Rebecca L. Orelli, Towards Integrated Reporting: Accounting Change in the Public Sector (Cham: Springer, 2017) p. 88.

191 Katsikas, Rossi and Orelli, Towards Integrated Reporting p. 89.

192 See Thomson, “But does sustainability need capitalism', p. 21. 


\section{References}

'An MIA-ACCA report sheds light on IR in Malaysia: Malaysian companies are eager to gain knowledge about integrated reporting and how it can benefit the organisation and its stakeholders, says a new MIA-ACCA report', ACCA Think Ahead, November 1, 2016. Retrieved from https://www.accaglobal.com/an/en/member/member/accounting-busi ness/2016/11-12/in-focus/ir-future.html.

Adams, Carol A., 'The International Integrated Reporting Council: A call to action', Critical Perspectives on Accounting, 27 (2015), 23-28. https://doi.org/10.1016/j.cpa.2014.07.001.

Adams, Carol A. and Glen Whelan, 'Conceptualising future change in corporate sustainability reporting’, Accounting, Auditing \& Accountability Journal, 22:1 (2009), pp. 118-143. https://doi.org/10.1108/09513570910923033.

Adams, Sarah and Roger Simnett, 'Integrated Reporting: An Opportunity for Australia's Not-forProfit Sector', Australian Accounting Review, 21:3 (2011), 292-301. https://doi.org/10.1111/ j.1835-2561.2011.00143.x.

Adhariani, Desi and Charl de Villiers, 'Integrated reporting: perspectives of corporate report preparers and other stakeholders', Sustainability Accounting,Management and Policy Journal Vol. 10(1) (2019), pp. 183-207. https://doi.org/10.1108/SAMPJ-02-2018-0043.

Aguilera, Ruth V. and Alvaro Cuervo-Cazurra, 'Codes of Good Governance Worldwide: What is the Trigger?', Organization Studies, 25:3 (2004), 417-446. https://doi.org/10.1177/ 0170840604040669.

Bebbington, Jan and Ian Thomson, 'Editorial: Sustainable development, management and accounting: Boundary crossing', Management Accounting Research, 24 (2013), 277-283. https://doi.org/10.1016/j.mar.2013.09.002.

Bocken, N.M.P., S.W. Short, P. Rana and S. Evans, 'A literature and practice review to develop sustainable business model archetypes', Journal of Cleaner Production, 65 (2014), 42-56. https://doi.org/10.1016/j.jclepro.2013.11.039.

Cheng, Mandy, Wendy Green, Pieter Conradie, Noriyuki Konishi and Andrea Romi, 'The international integrated reporting framework: key issues and future research opportunities', Journal of International Financial Management \& Accounting, 25:1 (2014), 90-119. https:// doi.org/10.1111/jifm.12015.

Churet, Cecile and Robert G. Eccles, 'Integrated Reporting, Quality of Management, and Financial Performance', Journal of Applied Corporate Finance, 26:1 (2014), 8-16. https:// doi.org/10.1111/jacf.12054.

Daly, Herman E. and Joshua Farley, Ecological Economics: Principles and Applications, 2nd ed. (Washington, DC: Island Press, 2011).

de Villiers, Charl, Elmar R. Venter and Pei-Chi Kelly Hsiao, 'Integrated reporting: background, measurement issues, approaches and an agenda for future research', Accounting \& Finance, 57 (2017), 937-959. https://doi.org/10.1111/acfi.12246.

de Villiers, Charl, Leonardo Rinaldi and Jeffrey Unerman, 'Integrated Reporting: Insights, gaps and an agenda for future research', Accounting, Auditing \& Accountability Journal, 27:7 (2014), 1042-1067. https://doi.org/10.1108/AAAJ-06-2014-1736.

Directive 2014/95/EU of the European Parliament and of the Council of October 22, 2014 amending Directive 2013/34/EU as regards disclosure of non-financial and diversity information by certain large undertakings and groups, OJ L 330, 15.11.2014, p. 1-9. 
Druckman, Paul, 'Foreword' in Chiara Mio (ed) Integrated Reporting: A New Accounting Disclosure (London: Palgrave Macmillan, 2016) pp. v-xi.

du Plessis, Jean J. and Andreas Rühmkorf, 'New trends regarding sustainability and integrated reporting for companies: what protection do directors have?', The Company Lawyer, 36 (2015), 49-62.

du Plessis, Jean J. and Chee Keong Low, 'Corporate Governance Codes Under the Spotlight' in Jean J. du Plessis and Chee Keong Low (eds), Corporate Governance Codes for the twentyfirst Century: International Perspectives and Critical Analyses (Cham: Springer, 2017) pp. 3-20.

Dumay, John, Cristiana Bernardi, James Guthrie and Matteo La Torre, 'Barriers to Implementing the International Integrated Reporting Framework: A Contemporary Academic Perspective', Meditari Accountancy Research, 25(4) (2017), 461-480. https://doi.org/10.1108/MEDAR05-2017-0150.

Dumay, John and Tim Dai, 'Integrated thinking as a cultural control?', Meditari Accountancy Research, 25:4 (2017), 574-604. https://doi.org/10.1108/MEDAR-07-2016-0067.

Eccles, Robert C., Michael P. Krzus and Sydney Ribot, The Integrated Reporting Movement: Meaning, Momentum, Motives, and Materiality (Hoboken: John Wiley \& Sons, 2015).

Ekins, Paul, Sandrine Simon, Lisa Deutsch, Carl Folke and Rudolf De Groot, 'A framework for the practical application of the concepts of critical natural capital and strong sustainability', Ecological Economics, 44 (2003), 165-185. https://doi.org/10.1016/S0921-8009(02) 00272-0.

Elkington, John, Cannibals with forks: The triple bottom line of Twenty-first century business (Oxford: Capstone, 1997).

Esser, Irene-Marie, 'Corporate Governance: Soft Law Regulation and Disclosure - The Cases of the United Kingdom and South Africa' in Jean J. Plessis du and Chee Keong Low (eds), Corporate Governance Codes for the twenty-first Century: International Perspectives and Critical Analyses (Cham: Springer, 2017) pp. 233-260.

Esser, Irene-Marie, 'Corporate Social Responsibility: A Company Law Perspective, South African Mercantile Law Journal 23 (2011), pp. 317-335.

EU High-Level Expert Group on Sustainable Finance, Financing a Sustainable European Economy: Interim Report (July 2017). Retrieved from https://ec.europa.eu/info/publica tions/170713-sustainable-finance-report_en.

High-Level Expert Group on Sustainable Finance, Financing a Sustainable European Economy: Final Report (January 2018). Retrieved from https://ec.europa.eu/info/sites/info/files/ 180131-sustainable-finance-final-report_en.pdf.

European Commission, Communication from the Commission to the European Parliament, the European Council, the Council, the European Central Bank, the European Economic and Social Committee and the Committee of the Regions, Action Plan: Financing Sustainable Growth, 8.3.2018, COM/2018/097 final.

European Commission, Proposal for a Regulation of the European Parliament and of the Council on disclosures relating to sustainable investments and sustainability risks and amending Directive (EU) 2016/2341, 24.5.2018, COM(2018) 354 final.

European Commission, Sustainable finance: The EU is examining how to integrate sustainability considerations into its financial policy framework in order to mobilise finance for sustainable growth. Retrieved from www.ec.europa.eu/info/business-economy-euro/bankingand-finance/sustainable-finance_en. 
Flower, John, 'The International Integrated Reporting Council: A story of failure', Critical Perspectives on Accounting, 27 (2015), 1-17. https://doi.org/10.1016/j.cpa.2014.07.002.

Freeman, R. Edward, Strategic Management: A Stakeholder Approach (Boston: Pitman, 1984). Gibassier, Delphine, Michelle Rodrigue and Diane-Laure Arjeliès, “IIntegrated reporting is like God: no one has met Him, but everybody talks about Him": The power of myths in the adoption of management innovations', Accounting, Auditing \& Accountability Journal, 31(5) (2018), 1349-1380. https://doi.org/10.1108/AAAJ-07-2016-2631.

Gleeson-White, Jane, Six Capitals: The revolution capitalism has to have - or can accountants save the planet? (Sydney: Allen and Unwin, 2014).

Global Reporting Initiative. Retrieved from www.globalreporting.org.

Gray, Rob, 'Social and Environmental Accounting and Reporting: From Ridicule to Revolution? From Hope to Hubris? - A Personal Review of the Field', Issues in Social and Environmental Accounting 2(1) (2008), 3-18.

Guillén, Mauro F. 'Corporate Governance and Globalization: Is There Convergence Across Countries?' in Thomas Clarke (ed), Theories of Corporate Governance: The philosophical foundations of corporate governance (London \& New York: Routledge, 2004) pp. 223-242.

Haji, Abdifatah Ahmed and Dewan Mahboob Hossain, 'Exploring the implications of integrated reporting on organisational reporting practice: Evidence from highly regarded integrated reporters', Qualitative Research in Accounting \& Management, 13(4) (2016), 415-444. https://doi.org/10.1108/QRAM-07-2015-0065.

Haller, Axel, 'Value Creation: A Core Concept of Integrated Reporting' in Chiara Mio (ed) Integrated Reporting: A New Accounting Disclosure (London: Palgrave Macmillan, 2016) pp. 37-57.

Harper Ho, Virginia, “'Enlightened Shareholder Value”: Corporate Governance beyond the Shareholder-Stakeholder Divide’ (2010) 36(1) Journal of Corporation Law 36 (1) (2010), 59-112.

Hess, David, 'Chapter 7: The Future of Sustainability Reporting as a Regulatory Mechanism' in Daniel R. Cahoy and Jamison E. Colburn (eds) Law and the Transition to Business Sustainability (Cham: Springer, 2014) pp. 125-139.

Higgins, Colin, Wendy Stubbs and Tyron Love, 'Walking the talk(s): Organisational narratives of integrated reporting', Accounting, Auditing \& Accountability Journal, 27:7 (2014), 10901119. https://doi.org/10.1108/AAAJ-04-2013-1303.

Holden, Erling, Kristin Linnerud and David Banister, 'Sustainable development: Our Common Future revisited’, Global Environmental Change 26 (2014), 130-139. https://doi.org/ 10.1016/j.gloenvcha.2014.04.006.

Hueskes, Marlies, Koen Verhoest and Thomas Block, 'Governing public-private partnerships for sustainability: An analysis of procurement and governance practices of PPP infrastructure projects', International Journal of Project Management, 35 (2017), 1184-1195. https://doi. org/10.1016/j.ijproman.2017.02.020.

Hugé, Jean, Tom Waas, Farid Dahdouh-Guebas, Nico Koedam and Thomas Block, 'A discourseanalytical perspective on sustainability assessment: interpreting sustainable development in practice', Sustainability Science, 8:2(2013), 187-198. https://doi.org/10.1007/s11625012-0184-2.

Humphrey, Christopher, O'DwyerBrendan and Jeffrey Unerman, 'Re-theorizing the configuration of organizational fields: the IIRC and the pursuit of 'Enlightened' corporate reporting', Accounting and Business Research, 47:1 (2017), 30-63. https://doi.org/10.1080/ 00014788.2016.1198683. 
Idowu, Samuel O. and Mara Del Baldo (eds), Integrated Reporting: Antecedents and Perspectives for Organizations and Stakeholders (Cham: Springer, 2019).

Institute of Directors in South Africa, King Code of Governance Principles for South Africa 2009 (King III). Retrieved from https://cdn.ymaws.com/www.iodsa.co.za/resource/resmgr/ king_iii/King_Report_on_Governance_fo.pdf.

Institute of Directors in Southern Africa, King IV Report on Corporate Governance for South Africa 2016 (King IV). Retrieved from https://cdn.ymaws.com/www.iodsa.co.za/resource/ collection/684B68A7-B768-465C-8214-E3A007F15A5A/IoDSA_King_IV_Report_-WebVersion.pdf.

Integrated Reporting 〈IR〉, 'New Malaysian Corporate Governance Code calls on companies to move towards Integrated Reporting'. Retrieved from https://integratedreporting.org/ news/new-malaysian-corporate-governance-code-calls-on-companies-to-move-towardsintegrated-reporting/.

Integrated Reporting Committee of South Africa, www.integratedreportingsa.org, Guidance in South Africa. Retrieved from http://integratedreportingsa.org/integrated-reporting/guidance/.

International Integrated Reporting Council, Consultation Draft of the International 〈IR Framework, International Integrated Reporting Council, London, April 2013. Retrieved from http://integratedreporting.org/wp-content/uploads/2013/03/Consultation-Draft-of-theInternationalIRFramework.pdf.

International Integrated Reporting Council, Integrated Reporting 〈IR〉. Retrieved from http:// integratedreporting.org.

International Integrated Reporting Council, IRC of South Africa: Integrated Reporting is a key feature of King IV, November 2, 2016. Retrieved from http://integratedreporting.org/news/ irc-of-south-africa-integrated-reporting-is-a-key-feature-of-king-iv/.

International Integrated Reporting Council, New Malaysian Corporate Governance Code calls on companies to move towards Integrated Reporting, April 26, 2017. Retrieved from https:// integratedreporting.org/news/new-malaysian-corporate-governance-code-calls-on-compa nies-to-move-towards-integrated-reporting/.

International Integrated Reporting Council, The International $\langle\mathbf{R}\rangle$ Framework. Retrieved from http://integratedreporting.org/wp-content/uploads/2015/03/13-12-08-THEINTERNATIONAL-IR-FRAMEWORK-2-1.pdf.

Jaffar, Nahariah, Nor, Azleen Shabrina Mohd, Selamat, Zarehan, 'Analysis of Voluntary Disclosure Before and After the Establishment of the Integrated Reporting Framework', Accounting and Finance Review 3(4) (2018), pp. 105-113. Retrieved from http://gatrenterprise.com/GATRJournals/pdf_files/AFR\%20Vol\%203(4)/2.\%20Nahariah\%20Jaffar.pdf.

Johari, Jalila and Komathy, 'Sustainability reporting and firm performance: evidence in Malaysia', International Journal of Accounting, Finance and Business 4 (17) (2019), 32-45. Retrieved from http://www.ijafb.com/PDF/IJAFB-2019-17-03-04.pdf.

Katsikas, Epameinondas, Francesca Manes Rossi and Rebecca L. Orelli, Towards Integrated Reporting: Accounting Change in the Public Sector (Cham: Springer, 2017).

Keay, Andrew, 'An Analytical Study of Board Accountability in Transnational Codes of Corporate Governance' in Jean Jacques Du Plessis and Chee Keong Low (eds), Corporate Governance Codes for the twenty-first Century: International Perspectives and Critical Analyses (Cham: Springer, 2017), pp. 117-143.

Keay, Andrew, 'Moving towards Stakeholderism? Constituency Statutes, Enlightened Shareholder Value, and More: Much Ado about Little?' (2011) European Business Law Review 22 (1)(2011), pp. 1-49. 
Keay, Andrew, The Corporate Objective (Oxford: Edward Elgar, 2011).

Keay, Andrew, The Enlightened Shareholder Value Principle and Corporate Governance

(Abingdon: Routledge 2013).

Klettner, Alice, Thomas Clarke and Martijn Boersma, 'The Governance of Corporate

Sustainability: Empirical Insights into the Development, Leadership and Implementation of Responsible Business Strategy', Journal of Business Ethics, 122 (2014), 145-165. https:// doi.org/10.1007/s10551-013-1750-y.

KPMG: Malaysia's Top 100 leads sustainability reporting practices, Borneo Post Online, October 25, 2018. Retrieved from https://www.theborneopost.com/2017/10/25/kpmg-malaysiastop-100-leads-sustainability-reporting-practices/.

Landrum, Nancy E. and Brian Ohsowski, 'Identifying Worldviews on Corporate Sustainability: A Content Analysis of Corporate Sustainability Reports', Business Strategy and the Environment 27 (2018), pp. 128-151. https://doi.org/10.1002/bse.1989.

Levy, David L., Halina Szejnwald Brown and Martin de Jong, 'The Contested Politics of Corporate Governance: The Case of the Global Reporting Initiative', Business \& Society, 49:1 (2010), 88-115. https://doi.org/10.1177/0007650309345420.

Lombard, Sulette and Tronel Joubert, 'The Legislative Response to the Shareholders V Stakeholders Debate: A Comparative Overview', Journal of Corporate Law Studies, 14:1 (2014), 211-240. https://doi.org/10.5235/14735970.14.1.211.

Lüdeke-Freund, Florian, Sarah Carroux, Alexandre Joyce, Lorenzo Massa and Henning Breuer, 'The sustainable business model pattern taxonomy- 45 patterns to support sustainabilityoriented business model innovation' Sustainable Production and Consumption, 15 (2018), 145-162. https://doi.org/10.1016/j.spc.2018.06.004.

Marcon, Carlo and Moreno Mancin, 'Empirical Evidence on Current Integrated Reporting Practices' in Chiara Mio (ed) Integrated Reporting: A New Accounting Disclosure (London: Palgrave Macmillan, 2016) pp. 59-80.

Marsden, Chris, 'Economics, the Financial Crisis and Corporate Responsibility', Corporate Governance: The International Journal of Business in Society, 10(4) (2010), 360-364. https://doi.org/10.1108/14720701011069597.

Milne, Markus J. and Rob Gray, 'W(h)ither Ecology? The Triple Bottom Line, the Global Reporting Initiative, and Corporate Sustainability Reporting', Journal of Business Ethics, 118 (2013), 12-29. https://doi.org/10.1007/s10551-012-1543-8.

Monciardini, David, John Dumay and Lucia Biondi, 'Integrated Reporting and EU Law: Competing, Converging or Complementary Regulatory Frameworks?' (June 6, 2017), University of Oslo Faculty of Law Research Paper, No. 2017-23. Retrieved from SSRN https://ssrn.com/abstract=2981674.

Moneva, José M., Pablo Archel and Carmen Correa, 'GRI and the camouflaging of corporate unsustainability’, Accounting Forum 30 (2006), pp. 121-137. https://doi.org/10.1016/j. accfor.2006.02.001.

Näsi, Juha, 'A Scandinavian approach to stakeholder thinking: An analysis of its theoretical and practical uses, 1964-1980' in Juha Näsi (ed.), Understanding Stakeholder Thinking (Helsinki: LSR-Julkaisut Oy, 1995), pp. 97-115.

Natural Capital Coalition, What is natural capital? Retrieved from https://naturalcapitalcoali tion.org/natural-capital-2/.

Neumayer, Erik, Weak Versus Strong Sustainability: Exploring the Limits of Two Opposing Paradigms (Cheltenham: Edward Elgar Publishing, 2003). 
Oliver, Judy, Gillian Vesty and Albie Brooks, 'Conceptualising integrated thinking in practice', Managerial Auditing Journal, 31:2 (2016), 228-248. https://doi.org/10.1108/MAJ-10-20151253.

Page, Michael and Laura F. Spira, 'Corporate governance as custodianship of the business model’, Journal of Management \& Governance, 20:2 (2016), 213-228. https://doi.org/ 10.1007/s10997-016-9343-7.

Patajo-Kapunan, Lorna, 'New code of corporate governance for publicly listed companies', February 12, 2017. Retrieved from http://www.businessmirror.com.ph/new-code-of-corpo rate-governance-for-publicly-listed-companies/.

Patala, Samuli, Anne Jalkala, Joona Keränen, Sanni Väisänen, Valtteri Tuominen and Risto Soukka, 'Sustainable value propositions: Framework and implications for technology suppliers' (2016) 59 Industrial Marketing Management 144-156. https://doi.org/10.1016/j. indmarman.2016.03.001.

Ramalho, Ansie, The link between codes of corporate governance and sustainability, on file with author.

Regulation of the European Parliament and of the Council on sustainability-related disclosures in the financial services sector (Text with EEA relevance), PE-CONS 87/19. Retrieved from https://data.consilium.europa.eu/doc/document/PE-87-2019-INIT/en/pdf.

Report of the Committee on The Financial Aspects of Corporate Governance (Cadbury Report), December 1, 1992. Retrieved from https://ecgi.global/sites/default/files//codes/docu ments/cadbury.pdf.

Rhenman, Eric, Företagsdemokrati och företagsorganisation [Industrial democracy and industrial management] (Stockholm: Thule, 1964).

Roberts, Leigh Georgia, 'Integrated Reporting: The South African Experience', The CPA Journal: The Voice of the Profession, July 2017, p. 12. Retrieved from https://www.cpajournal.com/ 2017/07/28/integrated-reporting-south-african-experience/.

Robinson, John, 'Squaring the circle? Some thoughts on the idea of sustainable development', Ecological Economics, 48 (2004), 369-384. https://doi.org/10.1016/j.ecolecon.2003.10.017.

Rodrigue, Michelle, 'The International Integrated Reporting Council: A Story of Failure; 'But Does Sustainability need Capitalism or an Integrated Report' a Commentary on 'The International Integrated Reporting Council: A Story of Failure' by Flower, J.; The International Integrated Reporting Council: A Call to Action', Social and Environmental Accountability Journal, 35:2 (2015), 128-129. https://doi.org/10.1080/0969160X.2015.1068568.

Roome, Nigel, 'Looking Back, Thinking Forward: Distinguishing Between Weak and Strong Sustainability' in Pratima Bansal and Andrew J. Hoffman (eds), The Oxford Handbook of Business and the Natural Environment (November 2011). doi: 10.1093/oxfordhb/ $9,780,199,584,451.003 .0034$.

Securities Commission Malaysia, Malaysian Code on Corporate Governance (2017). Retrieved from https://www.sc.com.my/api/documentms/download.ashx?id=70a5568b-1937-4d2b8cbf-3aefed112c0a.

Sejati, Yuyun A. and Jones, Christopher R., 'The Impact of Malaysian Code on Corporate Governance and Political Connections on Accounting Conservatism', Journal of Accounting and Finance 19(3) (2019), 115-132. https://doi.org/10.33423/jaf.v19i3.2036.

Stockholm Resilience Centre, Planetary boundaries research. Retrieved from https://www. stockholmresilience.org/research/planetary-boundaries.html. 
Strand, Robert and R. Edward Freeman, 'Scandinavian Cooperative Advantage: The Theory and Practice of Stakeholder Engagement in Scandinavia', Journal of Business Ethics 27 (2015), 65-85.

Stubbs, Wendy and Colin Higgins, 'Stakeholders' Perspectives on the Role of Regulatory Reform in Integrated Reporting', Journal of Business Ethics, 147 (2018), 489-508. https://doi.org/ 10.1007/s10551-015-2954-0.

Szabó, Daniél Gergely and Karsten Engsig Sørensen, 'Integrating Corporate Social Responsibility in Corporate Governance Codes in the EU', European Business Law Review 24(6) (2013), 781-828.

Teece, David J., 'Business Models, Business Strategy and Innovation', Long Range Planning 43 (2010), 172-194. https://doi.org/10.1016/j.lrp.2009.07.003.

Thomson, Ian, "But does sustainability need capitalism or an integrated report' a commentary on 'The International Integrated Reporting Council: A story of failure' by Flower, J.', Critical Perspectives on Accounting, 27 (2015), 18-22. https://doi.org/10.1016/j.cpa.2014.07.003.

Tsagas, Georgina, 'Section 172 of the Companies Act 2006: Desperate Times Call for Soft Law Measures' in Nina Boeger and Charlotte Villiers (eds) Shaping the Corporate Landscape: Towards Corporate Reform and Enterprise Diversity (Oxford and Portland, Oregon: Hart Publishing, 2018) pp. 131-150.

Tweedie, Dale and Nonna Martinov-Bennie, 'Entitlements and Time: Integrated Reporting’s Double-edged Agenda', Social and Environmental Accountability Journal, 35(1) (2015), 49-61. https://doi.org/10.1080/0969160X.2015.1007466.

Tweedie, Dale, Christian Nielsen and Nonna Martinov-Bennie, 'The Business Model in Integrated Reporting: Evaluating Concept and Application', Australian Accounting Review, 28(3) (2018), 405-420. https://doi.org/10.1111/auar.12196.

United Nations Environment Programme, Integrated Governance: A new model of governance for sustainability. A report by the Asset Management Working Group of the United Nations Environment Programme Finance Initiative, June 2014.

Velte, Patrick and Martin Stawinoga, 'Integrated reporting: The current state of empirical research, limitations and future research implications', Journal of Management Control, 28:3 (2017), 275-320. https://doi.org/10.1007/s00187-016-0235-4.

Victor, Peter A. 'Indicators of sustainable development: some lessons from capital theory', Ecological Economics, 4(3) (1991), 191-213. https://doi.org/10.1016/0921-8009(91)90051-F.

Villiers, Charlotte and Jukka Mähönen, 'Article 11: Integrated Reporting or Non-Financial Reporting?' in Beate Sjåfjell and Anja Wiesbrock (eds), The Greening of European Business under EU Law - Taking Article 11 TFEU Seriously (Abingdon: Routledge) pp. 118-143.

World Commission on Environment and Development, Our Common Future (Oxford University Press, 1987).

World Forum on Natural Capital, What is natural capital? Retrieved from https://naturalcapital forum.com/about/. 